\title{
INTERVERTEBRAL DISC AND ENDPLATE CELLS RESPONSE TO IL-1 $\beta$ INFLAMMATORY CELL PRIMING AND IDENTIFICATION OF MOLECULAR TARGETS OF TISSUE DEGENERATION
}

\author{
P. De Luca ${ }^{1}$, L. de Girolamo ${ }^{1}$, D. Kouroupis ${ }^{2}$, M. Castagnetta ${ }^{3}$, C. Perucca Orfei ${ }^{1}$, D. Coviello ${ }^{4}$, S. Coco $^{5}$, \\ D. Correa ${ }^{2,6}$, M. Brayda-Bruno ${ }^{7}$ and A. Colombini ${ }^{1, *}$
}

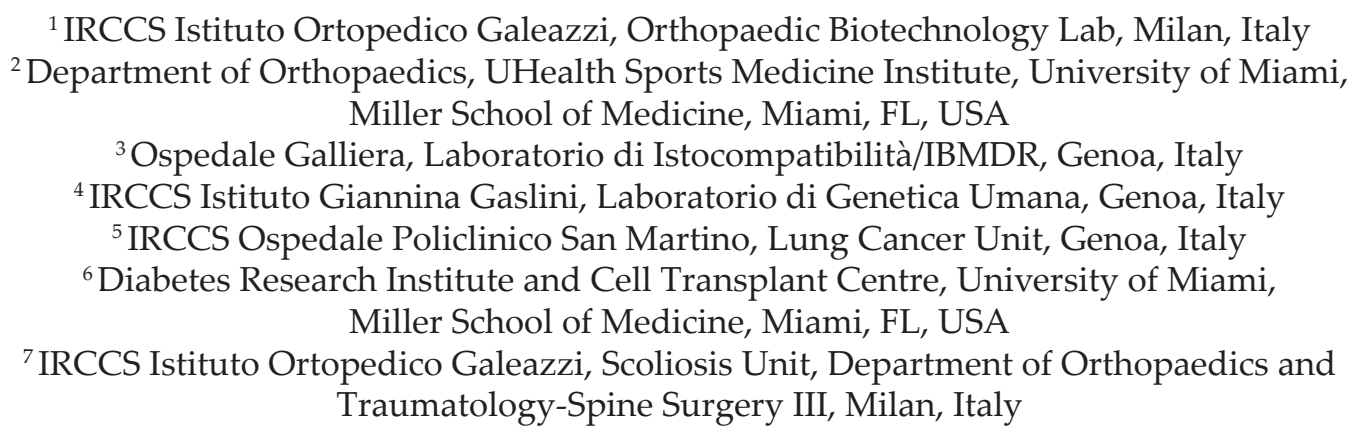

\begin{abstract}
Inflammation represents an important factor leading to metabolic imbalance within the intervertebral disc (IVD), conducive to degenerative changes. Therefore, a thorough knowledge of the IVD and endplate (EP) cell behaviour in such pathological environments is essential when designing regenerative therapeutic strategies. The present study aimed at assessing the molecular response of the IVD constitutive nucleus pulposus (NPCs)-, annulus fibrosus (AFCs)- and endplate (EPCs)-derived cells to interleukin (IL)-1 $\beta$ treatment, through largescale, high-throughput microarray and protein analysis, identifying the differentially expressed genes and released proteins. Overall, the inflammatory stimulus downregulated stemness genes while upregulating pro-inflammatory, pro-angiogenic and catabolic genes, including matrix metalloproteases, which were not balanced by a concomitant upregulation of their inhibitors. Upregulation of anti-inflammatory and anabolic tumour necrosis factor inducible gene 6 protein (TNFAIP6), of IL-1 receptor antagonist (IL-1Ra) (at gene and protein levels) and of trophic insulin-like growth factor 1 (IGF1) was also observed in all cell types; IGF1 particularly in AFCs. An overall inhibitory effect of tumour necrosis factor alpha (TNF $\alpha$ ) signal was observed in all cell types; however, EPCs showed the strongest anti-inflammatory behaviour. AFCs and EPCs shared the ability to limit the activation of the signalling mediated by specific chemokines. AFCs showed a slightly senescent attitude, with a downregulation of genes related to DNA repair or pro-mitosis.

Results allowed for the identification of specific molecular targets in IVD and EP cells that respond to an inflammatory environment. Such targets can be either silenced (when pathological targets) or stimulated to counteract the inflammation.
\end{abstract}

Keywords: Intervertebral disc cells, endplate cells, interleukin 1 beta, gene array, protein array, inflammation markers.

*Address for correspondence: Alessandra Colombini, Istituto Ortopedico Galeazzi, Orthopaedic Biotechnology Lab, Via R. Galeazzi 4, 20161, Milan, Italy.

Telephone number: +39 0266214067 Email: alessandra.colombini@grupposandonato.it

Copyright policy: This article is distributed in accordance with Creative Commons Attribution Licence (http://creativecommons.org/licenses/by-sa/4.0/).

\section{List of Abbreviations}

ADAMTS

ADGRB1 a disintegrin and metalloproteinase with thrombospondin motifs adhesion $G$ protein-coupled receptor B1

\section{$A D H 1 B$}

ADIPOQ

$\mathrm{AF}$

AFCs

ANGPT alcohol dehydrogenase $1 \mathrm{~B}$ adiponectin, C1Q and collagen domain containing annulus fibrosus AF cells angiopoietin 


\begin{tabular}{|c|c|c|c|}
\hline$A R P P 21$ & cAMP regulated phosphoprotein 21 & IGF & insulin-like growth factor \\
\hline $\mathrm{BCA}$ & bicinchoninic acid & IGFBP & IGF-binding protein \\
\hline BCL2 & BCL2 apoptosis regulator & IL & interleukin \\
\hline BCL2A1 & BCL2-related protein A1 & IL1R2 & interleukin 1 receptor type 2 \\
\hline$B L M$ & BLM RecQ-like helicase & IL-1Ra/IL1RN & IL-1 receptor antagonist \\
\hline$C 3 A R 1$ & $\begin{array}{l}\text { complement component } 3 \text { a receptor } \\
1\end{array}$ & $\begin{array}{l}\text { IL-6sR } \\
\text { INHBA }\end{array}$ & $\begin{array}{l}\text { IL-6 soluble receptor } \\
\text { inhibin subunit beta A }\end{array}$ \\
\hline$C C L$ & C-C motif chemokine ligand & iNOS & inducible nitric oxide synthase \\
\hline$C C R$ & $\mathrm{C}-\mathrm{C}$ chemokine receptor & IP-10 & interferon-gamma-induced protein \\
\hline CD40LG & CD40 ligand & & 10 \\
\hline CDH5 & cadherin 5 & IVD & intervertebral disc \\
\hline СЕВРВ & $\begin{array}{l}\text { CCAAT enhancer binding protein } \\
\text { beta }\end{array}$ & $\begin{array}{l}\text { KRAS } \\
\text { KYNU }\end{array}$ & $\begin{array}{l}\text { KRAS proto-oncogene, GTPase } \\
\text { kynureninase }\end{array}$ \\
\hline CHEK1 & checkpoint kinase 1 & LAMP5 & lysosomal associated membrane \\
\hline CHGA & chromogranin A & & protein family member 5 \\
\hline CHI3L1 & chitinase-3-like & LCN2 & lipocalin 2 \\
\hline CILP2 & $\begin{array}{l}\text { cartilage intermediate layer protein } \\
2\end{array}$ & $\begin{array}{l}\text { LDB2 } \\
\text { LEFTY2 }\end{array}$ & $\begin{array}{l}\text { LIM domain binding } 2 \\
\text { left-right determination factor } 2\end{array}$ \\
\hline CLCA2 & chloride channel accessory 2 & LEP & leptin \\
\hline CLIC6 & chloride intracellular channel 6 & LIF & LIF interleukin 6 family cytokine \\
\hline СMPK2 & $\begin{array}{l}\text { cytidine/uridine monophosphate } \\
\text { kinase } 2\end{array}$ & $\begin{array}{l}\text { LRRN3 } \\
\text { LSP1 }\end{array}$ & $\begin{array}{l}\text { leucine rich repeat neuronal } 3 \\
\text { lymphocyte specific protein } 1\end{array}$ \\
\hline CNMD & chondromodulin & $L T A$ & lymphotoxin alpha \\
\hline COL4A3 & collagen type IV alpha 3 chain & $L T B$ & lymphotoxin beta \\
\hline CSF & colony stimulating factor & LYVE1 & lymphatic vessel endothelial \\
\hline CSF1R & CSF 1 receptor & & hyaluronan receptor 1 \\
\hline CXCL & C-X-C motif chemokine ligand & MAP1LC3C & microtubule associated protein 1 \\
\hline CXCR & C-X-C motif chemokine receptor & & light chain 3 gamma \\
\hline DCLRE1B & DNA cross-link repair 1B & MCP-1 & monocyte chemoattractant protein 1 \\
\hline ECM & extracellular matrix & MIP & macrophage inflammatory protein \\
\hline EGF & epidermal growth factor & MMPs & metalloproteinases \\
\hline$E H F$ & ETS homologous factor & MSC & mesenchymal stem/stromal cell \\
\hline \multirow[t]{2}{*}{ ELISA } & enzyme-linked immunosorbent & MSTN & myostatin \\
\hline & assay & MYBPH & myosin binding protein $\mathrm{H}$ \\
\hline \multirow[t]{2}{*}{ EME1 } & essential meiotic structure-specific & MYL1 & myosin light chain 1 \\
\hline & endonuclease 1 & NAMPT & nicotinamide \\
\hline $\mathrm{EP}$ & endplate & & phosphoribosyltransferase \\
\hline EPCs & EP cells & NEFM & neurofilament medium \\
\hline EREG & epiregulin & NEURL3 & neuralised E3 ubiquitin protein \\
\hline F3 & coagulation factor III, tissue factor & & ligase 3 \\
\hline FASLG & Fas ligand & NO & nitric oxide \\
\hline FBS & foetal bovine serum & NOD2 & nucleotide binding oligomerisation \\
\hline Fc & fold change & & domain containing 2 \\
\hline FGF & fibroblast growth factor & NOS & NO synthase \\
\hline \multirow[t]{2}{*}{ FGFBP1 } & fibroblast growth factor binding & NOTCH4 & notch receptor 4 \\
\hline & protein 1 & NOX1 & NADPH oxidase 1 \\
\hline FGFR3 & fibroblast growth factor receptor 3 & NP & nucleus pulposus \\
\hline FST & follistatin & NPCs & NP cells \\
\hline GDF & growth differentiation factor & $N R 4 A 3$ & nuclear receptor subfamily 4 group \\
\hline \multirow[t]{2}{*}{ GM-CSF } & granulocyte-macrophage colony & & A member 3 \\
\hline & stimulating factor & NRG1 & neuregulin 1 \\
\hline GRP & gastrin releasing peptide & $N R P$ & natriuretic peptide receptor \\
\hline \multirow[t]{2}{*}{ HEPES } & 4-(2-hydroxyethyl)-1- & NTF4 & neurotrophin 4 \\
\hline & piperazineethanesulphonic acid & OLFML & olfactomedin-like \\
\hline \multirow[t]{2}{*}{ HG-DMEM } & high-glucose Dulbecco's modified & OSM & oncostatin M \\
\hline & Eagle's medium & P3 & passage 3 \\
\hline ICAM & intercellular adhesion molecule 1 & PBMCs & peripheral blood mononuclear cells \\
\hline IDO & indoleamine 2,3-dioxygenase & PDE5A & phosphodiesterase $5 \mathrm{~A}$ \\
\hline IFI & interferon alpha inducible protein & PDGF & platelet-derived growth factor \\
\hline$I F N$ & interferon & $P L G$ & plasminogen \\
\hline
\end{tabular}


PLK1

PPARG

PRKCB

RASD1

RIMS1

RIN

RIPK2

RNH1

RSAD2

RSPO3

S100A8

SCRG1

SELE

SIRT2

SLC

SLPI

SMOC2

SOSTDC1

SPINK5

SPP1

SD

STNF-RI

TBP

TDO2

TGF

TGFBR1

Th

TIMP

TLR

TNF $\alpha$

TNFAIP6

TNFRSF1B

TNFSF

TPH1

TWIST2

TYMP

TSG-6

VCAM1

VEGF
PPP2R1B

PROK

PTGS1

polo-like kinase 1

peroxisome proliferator activated receptor gamma

protein phosphatase 2 scaffold

subunit A beta

protein kinase $\mathrm{C}$ beta

prokineticin

prostaglandin-endoperoxide

synthase 1

Ras-related dexamethasone induced

1

regulating synaptic membrane

exocytosis 1

RNA integrity number

receptor interacting serine/threonine

kinase 2

ribonuclease/angiogenin inhibitor 1

radical S-adenosyl methionine

domain containing 2

R-spondin 3

S100 calcium binding protein A8

stimulator of chondrogenesis 1

selectin E

sirtuin 2

solute carrier

secretory leukocyte peptidase

inhibitor

SPARC-related modular calcium

binding 2

sclerostin domain containing 1

serine peptidase inhibitor Kazal type 5

secreted phosphoprotein 1

standard deviation

soluble tumour necrosis factor

receptor I

TATA-box binding protein

tryptophan 2,3-dioxygenase

transforming growth factor

transforming growth factor beta

receptor 1

$\mathrm{T}$ helper

tissue inhibitor of MMP

toll-like receptor

tumour necrosis factor alpha

TNF inducible gene 6 protein

TNF receptor superfamily member $1 \mathrm{~B}$

TNF superfamily member

tryptophan hydroxylase 1

twist family bHLH transcription

factor 2

thymidine phosphorylase

TNF-stimulated gene 6

vascular cell adhesion molecule 1

vascular endothelial growth factor

\section{Introduction}

Around 540 million people worldwide suffer from low-back pain (Web ref. 1), mainly due to spine disorders strictly associated with age-related degenerative processes of the IVD (RodriguesPinto et al., 2014). These disorders have high socioeconomic costs related both to their long-lasting but transiently beneficial multidisciplinary management (i.e. conservative, analgesic or surgical) and to the progression of the IVD degeneration (Raj, 2008). For these reasons, the development of biological strategies to counteract IVD degeneration (Hughes et al., 2012) would be a valuable alternative to the current clinical management. In this context, a clear understanding of anatomical and pathophysiological features of the IVD is crucial (Colombini et al., 2008).

The IVD is a heterogeneous structure composed of a central NP, a surrounding AF and a bonycartilaginous EP delimiting the disc. The functional properties of the disc (e.g. mechanical) largely depend on the integrity of the physiological ECM, produced, maintained and remodelled by few resident cells. Alterations to the cellular metabolism adversely affect the tissue composition and performance, providing a starting point for degenerative changes (Colombini et al., 2008).

Maintenance of the metabolic balance in the IVD is a delicate equilibrium, because of a predominant chronic catabolic environment under pathological conditions. This condition is driven and sustained by the presence of higher levels of pro-inflammatory cytokines (Risbud and Shapiro, 2014), mainly TNF $\alpha$ and IL-1ß (Burke et al., 2002; Hamamoto et al., 2012; Le Maitre et al., 2005; Le Maitre et al., 2003; Risbud and Shapiro, 2014; Solovieva et al., 2004), and ECMdegrading enzymes, such as matrix MMPs and ADAMTS (Kepler et al., 2013; Le Maitre et al., 2004; Wang et al., 2011), associated with low levels of their inhibitors (TIMPs) (Liao et al., 2019; Vergroesen et al., 2015). Subpopulations of human NPCs, AFCs and EPCs showing phenotypic plasticity and a stem-like immunophenotype are present in degenerated IVDs (Brisby et al., 2013; Liu et al., 2011; Wang et al., 2016) and ideally would represent tissue specific cells to be used in therapies aiming at counteracting the degenerative microenvironment.

De Luca et al. (2020) have recently reported that NP, $\mathrm{AF}$ and EP cell populations isolated from pathological IVDs and EPs express specific phenotypic and stemness markers, as well as clonogenic, adipogenic and osteogenic potential, similar to MSC cells. Considerable similarities in pro-inflammatory and ECM-degrading factors involved in the degenerative processes have been observed in articular cartilage and IVD (Rustenburg et al., 2018). In fact, as for IVD and EP, chondrogenic progenitor cells have been found in human cartilage obtained from osteoarthritic patients and, together with chondrocytes, they show an increased secretion of cytokines and expression of MMPs, without a corresponding production of TIMPs after IL-1 $\beta$ stimulation (De Luca et al., 2019).

Given the significant impact of the local environment on cell behaviour, the analysis of potential IVD cellular alterations in response to inflammatory conditions becomes essential. 
The in vitro exposure of human IVD cells to IL-1 $\beta$ and TNF- $\alpha$, the two main inflammatory mediators involved in IVD degeneration, causes the upregulation of inflammatory molecules such as iNOS, NO, IL-1 $\beta$, IL-6, IL-8, IL-20, prostaglandin 2 and TNF- $\alpha$ (Kang et al., 1997; Klawitter et al., 2012a; Klawitter et al., 2012b; Millward-Sadler et al., 2009; Sinclair et al., 2011; Wuertz et al., 2011; Wuertz et al., 2013). Furthermore, both mediators also contribute to disc disease through the induction of the catabolic enzymes ADAMTS-4, -5 and MMP-1, -2, -3, -4, -13, -14 and the concomitant decreased expression of connective tissue growth factor, aggrecan and type II collagen, leading to a progressive ECM degradation (Bachmeier et al., 2009; Jimbo et al., 2005; Johnson et al., 2015; Le Maitre et al., 2005; Séguin et al., 2005; Wang et al., 2011; Wang et al., 2014; Tran et al., 2010; Tran et al., 2014). Nevertheless, although it is not definitively established whether either IL-1 $\beta$, TNF- $\alpha-$ or both drive ECM degradation, IL-1 $\beta$ is the key cytokine involved in this process (Hoyland et al., 2008; Le Maitre et al., 2007).

Based on this evidence, there are resulting issues that are of particular interest. To the best of the authors' knowledge, the molecular responses of NPCs, AFCs and EPCs to inflammatory and catabolic environments have not yet been fully investigated. Consequently, the aim of the present study was to investigate the response of NPCs, AFCs and EPCs to IL-1 $\beta$, a master regulator of IVD catabolic processes (Phillips et al., 2015), using large-scale highthroughput microarray and protein array analyses to identify differentially expressed genes and released proteins. These findings would provide new insights into the molecular targets of tissue degeneration, defining the usefulness of this specific inflammatory cell priming, and help identify the best resident and highly specialised cell agent to be used/stimulated in harsh condition for the treatment of disc degenerative processes.

\section{Materials and Methods}

\section{Cell isolation and expansion}

The study was approved by the Institutional Review Board (Protocol GenVDisc Version 1, 20 November 2015) and specimens were collected after patient informed consent was given. NP, AF from lumbar IVDs and EP of 3 male and 1 female patients (average age 50.5 years) affected by discopathy were harvested during discectomy through a careful macroscopic dissection performed by an experienced surgeon, discriminating the lamellar AF and the jelly-like NP and avoiding the transitional zone of the inner AF. NPCs, AFCs and EPCs were isolated by enzymatic digestion as previously described (Colombini et al., 2015; Lopa et al., 2016). The cell populations were cultured in control medium consisting of $4.5 \mathrm{mg} / \mathrm{mL}$ HG-DMEM, supplemented with 10 \% FBS (Lonza),
$0.29 \mathrm{mg} / \mathrm{mL}$ L-glutamine, $100 \mathrm{U} / \mathrm{mL}$ penicillin, $100 \mathrm{\mu g} /$ $\mathrm{mL}$ streptomycin, $10 \mathrm{mM}$ HEPES, $1 \mathrm{mM}$ sodium pyruvate (all from Life Technologies). Cells were seeded at $5 \times 10^{3}$ cells $/ \mathrm{cm}^{2}$ and expanded up to P3.

\section{In vitro model of inflammation}

Cells at P3 were stimulated by adding $1 \mathrm{ng} / \mathrm{mL}$ IL$1 \beta$ to the culture medium for $48 \mathrm{~h}$ according to a previously validated in vitro model of IVD and EP cell inflammation (De Luca et al., 2018; Kim et al., 2013). Then, supernatants and cells were collected for further analyses.

\section{RNA isolation and quality assessment for microarray analysis}

RNA was isolated from a pool of cells obtained from 4 donors by RNeasy Plus Mini Kit (Qiagen). Residual genomic DNA digestion was performed using RNase-Free DNase Set (Qiagen). RNA quantification and quality control were performed spectrophotometrically (Nanodrop, Thermo Scientific). RIN (value range from 1, totally degraded, to 10, intact) was evaluated by Agilent RNA ScreenTape System (Agilent Technologies). All RNA samples were intact and showed a RIN value of 10 .

\section{Gene expression microarray}

The expression profiling was performed using a custom-made gene expression microarray, allowing for the analyses of a maximum of 3000 genes considering a minimum of 5 replicates for each gene. The custom-made array was constructed based on an Agilent Technologies algorithm (Web ref. 2). Gene symbols and NM of the selected genes divided into housekeeping (14), chondrogenic/IVD/growth factors- (332), stemness- (1279), inflammation- (235), senescence- (140) and angiogenic-related (79) genes are reported in Supplementary Table 1. The choice of the genes of interest was performed based on the ones previously analysed (Takahashi et al., 2007; Xu et al., 2008; Yoo et al., 2011) or present in commercially available microarray and, then, implemented with genes analysed in studies focusing on the IVD (Liu et al., 2015; Minogue et al., 2010; Power et al., 2011; Rutges et al., 2010; Tang et al., 2012).

cRNA was obtained from 100 ng of total RNA that was labelled and amplified using a Low Input Quick Amp Labeling Kit, one-color. A spike mix was also added to each RNA sample (One-Color RNA Spike-In Kit) to obtain the correct annealing between 10 optimised positive control transcripts and the complementary probes on the chip. Then, auto- and cross-hybridisation was evaluated. Next, cRNA was purified using the RNeasy ${ }^{\circledR}$ Plus Mini Kit (Qiagen) and employed for the slide hybridisation using the Gene Expression Hybridization Kit. To obtain a highresolution image of the fluorescence values for each probe, the chip was washed and processed using the SureScan Microarray Scanner and Feature Extraction 12.0 software. Data analysis was performed by 
Genespring GX software. Reagents, instruments and software were purchased by Agilent Technologies, unless differently specified.

The ontology-based pathway analyses were performed using Panther, NCBI, QuickGO and GeneCards databases. Only values with an $\mathrm{FC}_{\mathrm{C}} \leq-2$ or $\geq+2$ were considered. Heat maps were generated using the online package ClustVis (Metsalu et al., 2015; Web ref. 3).

\section{Gene expression analysis through real-time PCR}

The expression of the most common inhibitors of MMPs, TIMP1 (Hs00171558, Life Technologies) and TIMP3 (Hs00165949, Life Technologies), was evaluated also by real-time PCR. For consistency, also the expression of MMP1 (Hs00899658, Life Technologies), MMP3 (Hs00968305, Life Technologies) and MMP13 (Hs00233992, Life Technologies) was assessed through the same method. The evaluation was performed at P3 and after IL-1 $\beta$ treatment in a total of 8 donors: the same 4 donors as used for the pool of gene and protein arrays and 4 new donors (mean age $51.9 \pm 6.9$ years; 4 males and 4 females) to strengthen and validate the results obtained from the other assays.

RNA was isolated from all cells using the RNeasy $^{\circledR}$ Plus Mini Kit (Qiagen), subsequently quantified spectrophotometrically (NanoDrop, Thermo Scientific) and reverse-transcribed with the iScript cDNA Synthesis Kit (Bio-Rad Laboratories). Gene expression was evaluated by real-time PCR (StepOne Plus, Life Technologies) using TaqMan ${ }^{\circledR}$ Gene Expression Master Mix and TaqMan ${ }^{\circledR}$ Gene Expression Assays (Life Technologies).

Since TBP (Hs00427620_m1, Life Technologies) represents the most stable gene observed in the array, according to previously published data (Lopa et al., 2016), it was chosen as the housekeeping gene. Data are expressed as Fc according to the $\Delta \mathrm{Ct}$ method.

\section{Protein array}

ELISA-based protein arrays (RayBio ${ }^{\circledR}$ C-Series, RayBiotech, Peachtree Corners, GA, USA) were used to evaluate the levels of inflammatory mediators in culture media obtained from disc cells, stimulated or not with IL-1 $\beta$. For each cell population, conditioned media were obtained from 4 donors, pooling 3 technical replicates for each of them. Data were normalised by the total protein content through BCA assay. The arrays showed a detection sensitivity up to $\mathrm{pg} / \mathrm{mL}$ of protein and were performed following the manufacturer's instructions. Data represent $40 \mathrm{~s}$ exposures in a FluorChem E chemiluminescence imaging system (ProteinSimple, San Jose, CA, USA). Results were generated by quantifying the mean spot pixel density using the protein array analyser of ImageJ (NIH website). The signal intensities were normalised to the background, whereas separate signal intensity results represented the average pixel density of two spots per inflammatory mediator. The relative concentration of the antigen in the sample was proportional to the signal intensity for each spot.

\section{Determination of IL-1Ra}

The levels of soluble IL-1Ra in cell culture medium after $48 \mathrm{~h}$ of treatment with IL- $1 \beta$ were determined for 8 total donors, as aforementioned, by a commercially available ELISA assay, according to the manufacturers' instructions (PeproTech). The detection range was 23$1500 \mathrm{pg} / \mathrm{mL}$.

\section{Statistical analysis}

Data are expressed as mean \pm SD. Normal distribution of values was assessed by the Kolmogorov-Smirnov normality test. Statistical analysis was performed using paired and unpaired Student's $t$-test for normally distributed data and Wilcoxon (for paired data) or Mann-Whitney (for unpaired data) test in the presence of a non-normal distribution (GraphPad Prism v5.00; GraphPad Software). Level of significance was set at $p<0.05$.

\section{Results}

\section{Gene expression analysis}

Stemness-related genes

After IL-1 $\beta$ treatment, 320 genes out of 1279 were modulated. Among these, 47 were upregulated, 271 downregulated and 2 either upregulated or downregulated in different cell populations (Supplementary Table 2). The three cell types shared 16 upregulated and 32 downregulated genes. Concerning the downregulated genes, 86 were found in NPCs, 123 in AFCs and 139 in EPCs. Heat maps and clustering showed that NPCs and EPCs shared similar behaviours in term of entity of stemness genes upregulation (Fig. 1a) or downregulation (Fig. 1b) after IL-1 $\beta$ treatment. In Supplementary Table 2 $\mathrm{Fc} \geq+2$ or $\leq-2$ are reported.

\section{Inflammation-related genes}

After IL-1 $\beta$ stimulation, NPCs, AFCs and EPCs showed an upregulation of 77 out of 235 genes related to inflammation (either upregulated or downregulated in the different cell populations), 53 of which shared by the three cell types (Fig. 2). Among the shared genes, there were those coding for SPP1 and MMP2, MMP3, MMP7, MMP10, MMP12 and $M M P 13$, involved in catabolic pathways. The upregulation of $M M P 3$ and MMP13 after IL-1 $\beta$ treatment was confirmed by real-time PCR, which revealed also an upregulation of $M M P 1$, without a corresponding upregulation of their inhibitors TIMP1 and TIMP3. The latter was in fact downregulated in all cell types (Fig. 3). IDO1, KYNU, NAMPT, SAAS and TNFAIP6, also belonging to metabolic pathways, were upregulated in all three cell populations. The reactive free radical NOS2, IL6, CXCL8, IL1 $\alpha, I L 1 \beta$, 
IL17C, SELE, the chemokine ligands CXCL1, CXCL2, CXCL3, CXCL5, CXCL6, CXCL8, CXCL10, CCL2, CCL3, CCL5, CCL7, CCL20, their receptors CXCR3, CXCR4 and CCR7 and the complement component $C 3$, all involved in pro-inflammatory pathways, were upregulated. An upregulation of CSF2, CSF3, IFI27, IL11, IL23A, LCN2, LIF, NOD2, OSM, RSAD2 and of the anti-inflammatory ILIRN was also observed. The anti-apoptotic $B C L 2 A 1$ and INHBA, related to TGF signalling cascade, and EHF, RSPO3, LRRN3, RASD1 and SLC7A2 were also upregulated in all three cell populations. NPCs and AFCs had in common the upregulation of CMPK2, RIPK2 and IFI44L, AFCs and EPCs shared the upregulation of NEFM, NR4A3 and of the pro-inflammatory CCL4, CCL11 and CCL13. Finally, NPCs and EPCs shared the upregulation $\mathbf{a}$

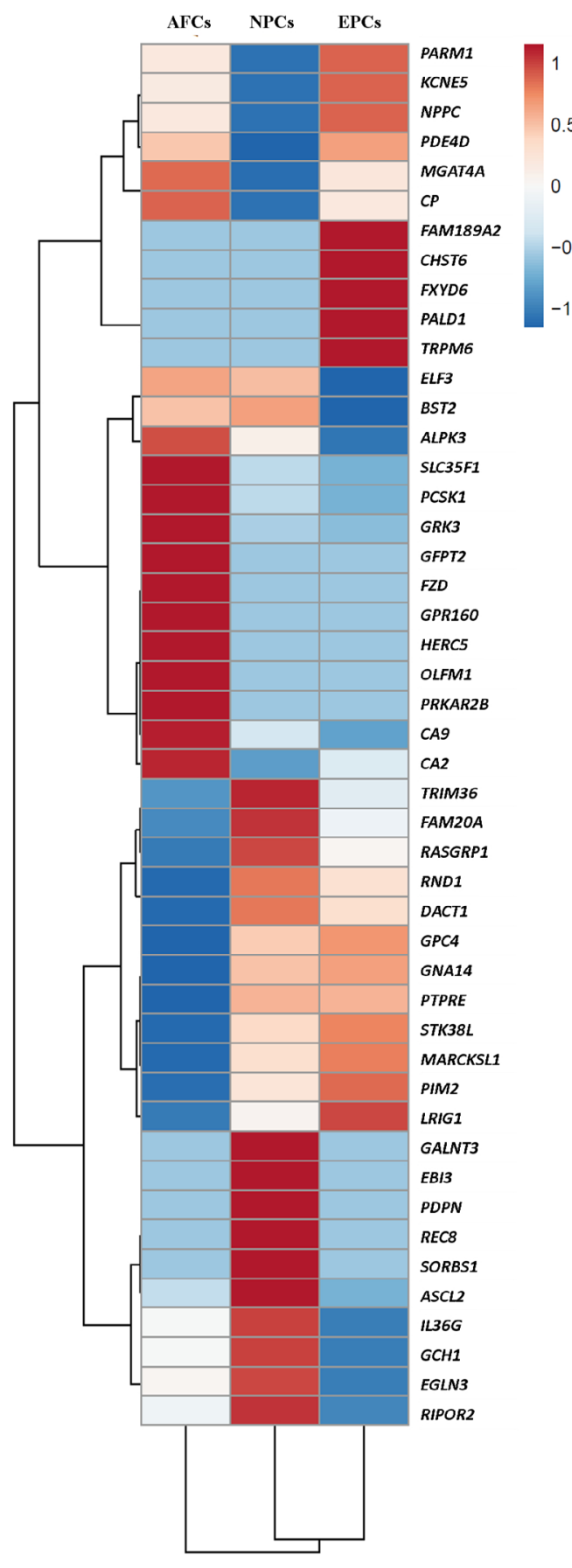

b

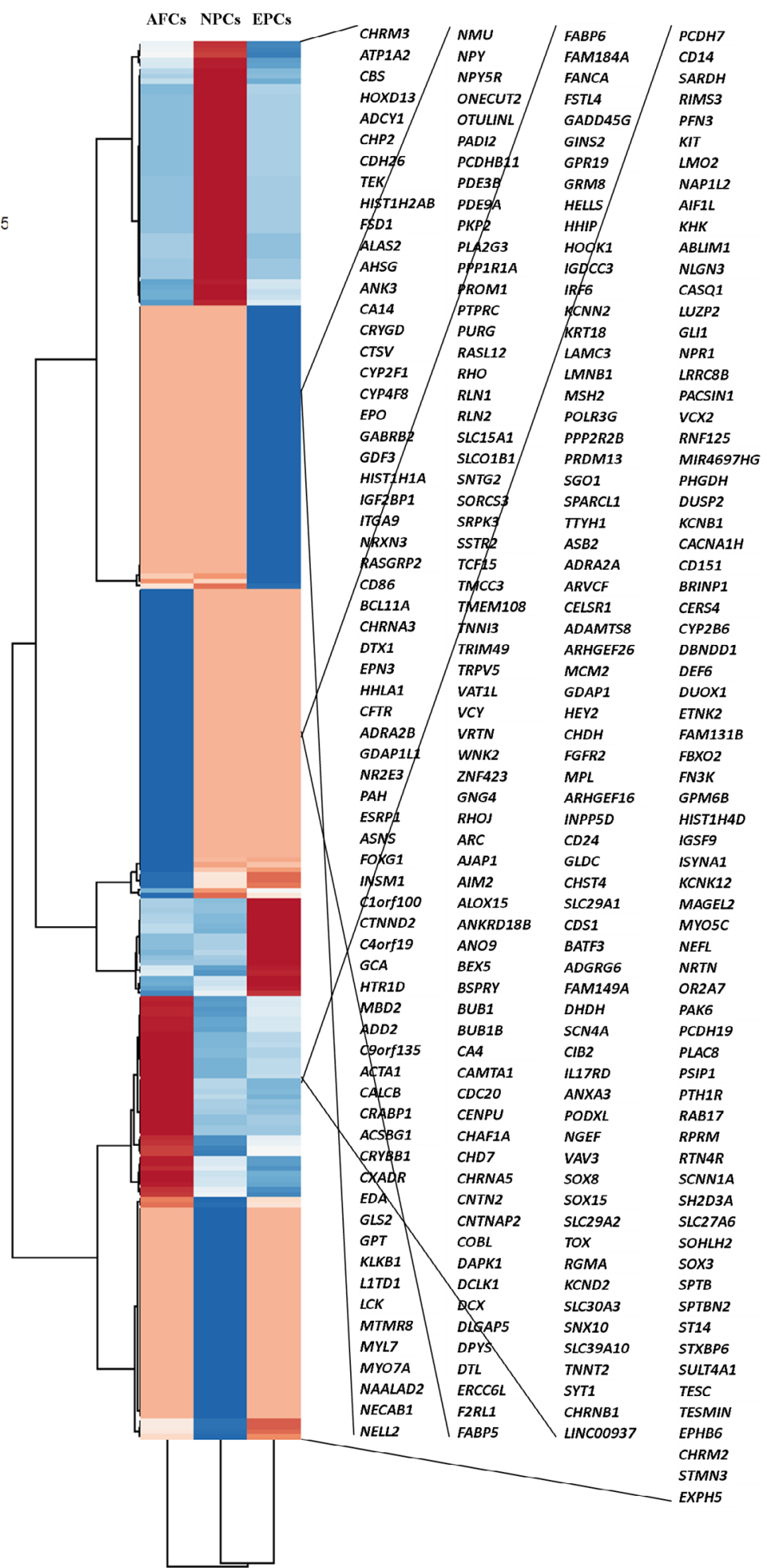

Fig. 1. Heat maps and clustering representing the stemness-related genes modulated by IL-1 $\beta$ treatment. (a) Upregulated $(\mathrm{Fc} \geq+2)$ and (b) downregulated ( $\mathrm{Fc} \leq-2)$ genes $(n=4)$. 
of the pro-inflammatory IL32, SERPINB2 and the anti-apoptotic TNFRSF1B. TNF and VCAM1 were upregulated only in NPCs; the catabolic ADAMTS4 and ADAMTS9 as well as CCL26, CXCL9, CLIC6, NEURL3 and TWIST2 only in AFCs. The antiinflammatory IL1R2, the pro-inflammatory IL20 and CEBPB, CHI3L2 and SLPI were instead exclusively upregulated in EPCs.

IL-1 $\beta$ treatment caused the downregulation of 79 out of 235 genes related to inflammation, of which 18 in common among the three cell populations (Fig. 2b): the catabolic ADAMTS15; the pro-inflammatory
CCL22, CCR1 and IL17A; the metabolic ADH1B, PDE5A, SCRG1 and SLC40A. Similarly, GDF5 and RIMS1 were downregulated as well as $L A M P 5, L D B 2$, LSP1, MAP1LC3C, MYBPH, OLFML2A, OLFML2B and SMOC2. Interestingly, AFCs and EPCs shared a downregulation of 42 genes belonging to different pathways: the pro-inflammatory C3AR1, CCL17, CCL21, CCL24, CCR2, CCR4, CCR5, CCR6, CXCR2 and IFNG; the anti-inflammatory CXCL4, IL4, IL5, IL13; genes involved in cytokine pathways such as IFNA1, IFNA2, IFNA4, IFNA5, IL12B, IL2, IL9, IL21, IL22, IL23R, LTB, TNFSF8 and CD40LG. Furthermore,
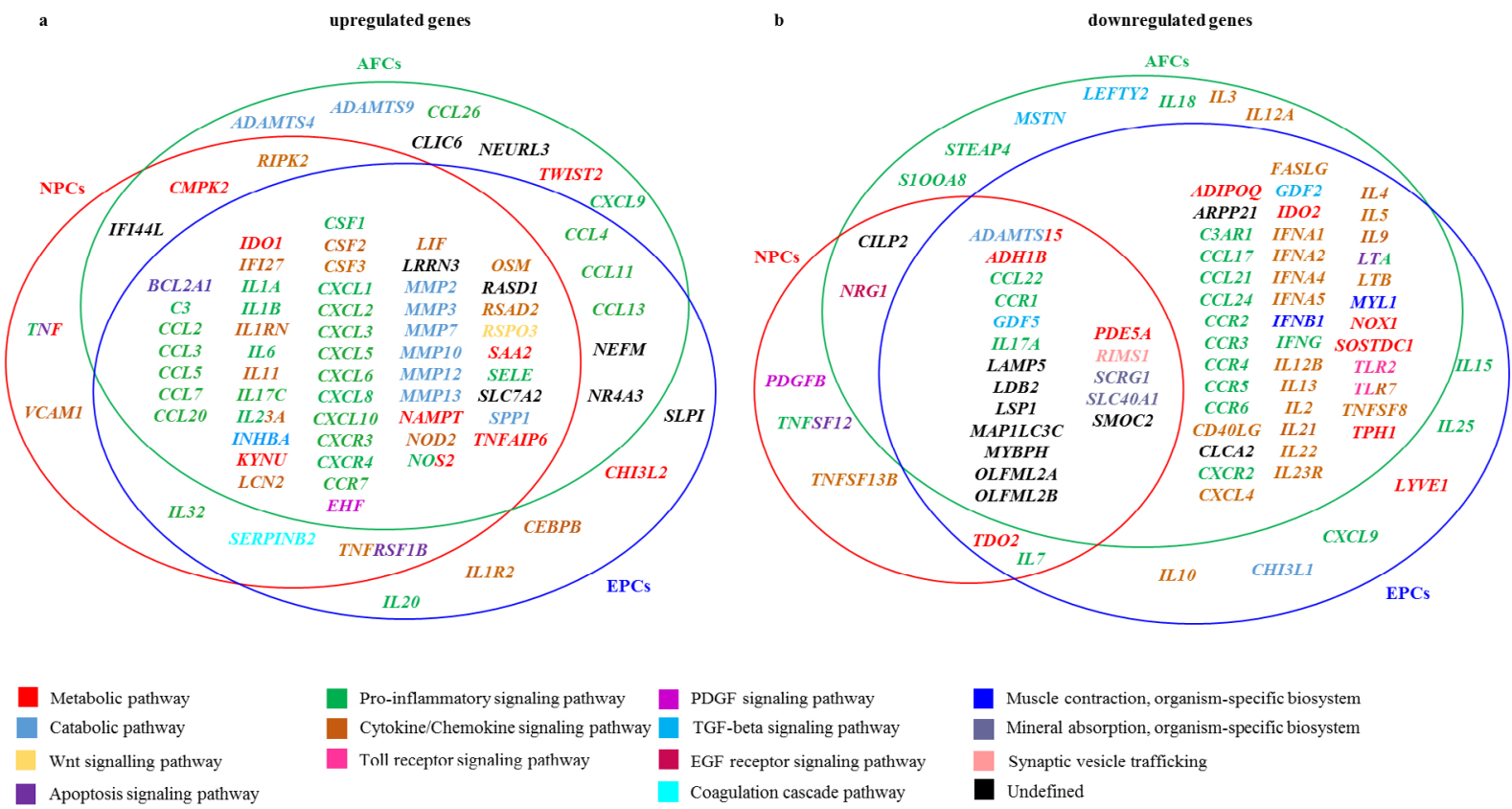

Muscle contraction, organism-specific biosystem Mineral absorption, organism-specific biosystem Synaptic vesicle trafficking

Undefined

Fig. 2. Venn diagram showing all the genes belonging to the inflammation panel modulated by IL-1 $\beta$ treatment. (a) Upregulated $(\mathrm{Fc} \geq+2)$ and (b) downregulated $(\mathrm{Fc} \leq-2)$ genes and the respective pathway, single or in common with the other cell populations $(n=4)$.
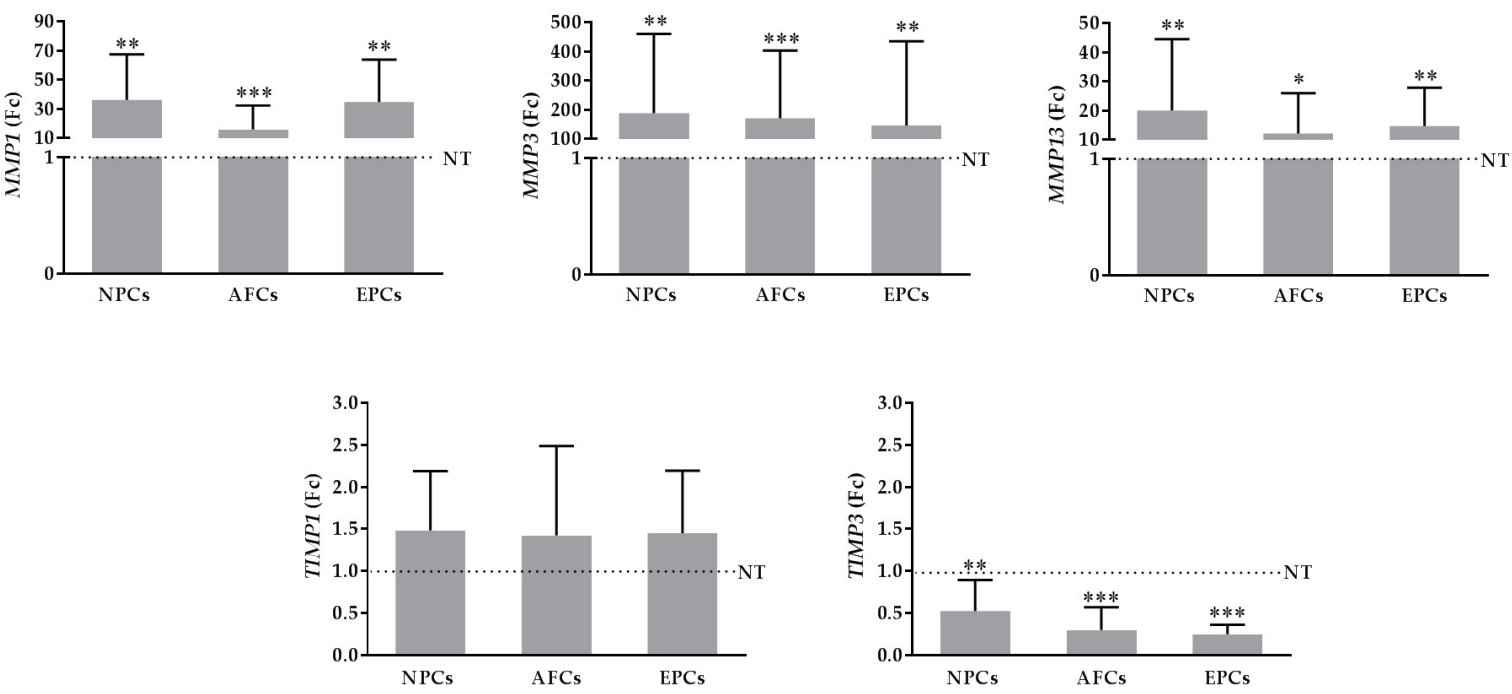

Fig. 3. Gene expression analysis (real-time PCR) represented as Fc of MMPs (MMP1, MMP3, MMP13) and their inhibitors (TIMP1, TIMP3) with respect to each non-treated sample (NT). ${ }^{*} p \leq 0.05,{ }^{* *} p \leq 0.01$ and ${ }^{* * *} p \leq 0.001$ indicate IL-1 $\beta$ treated $v s$. NT, in each cell populations $(n=8)$. Data are expressed as mean \pm SD. 

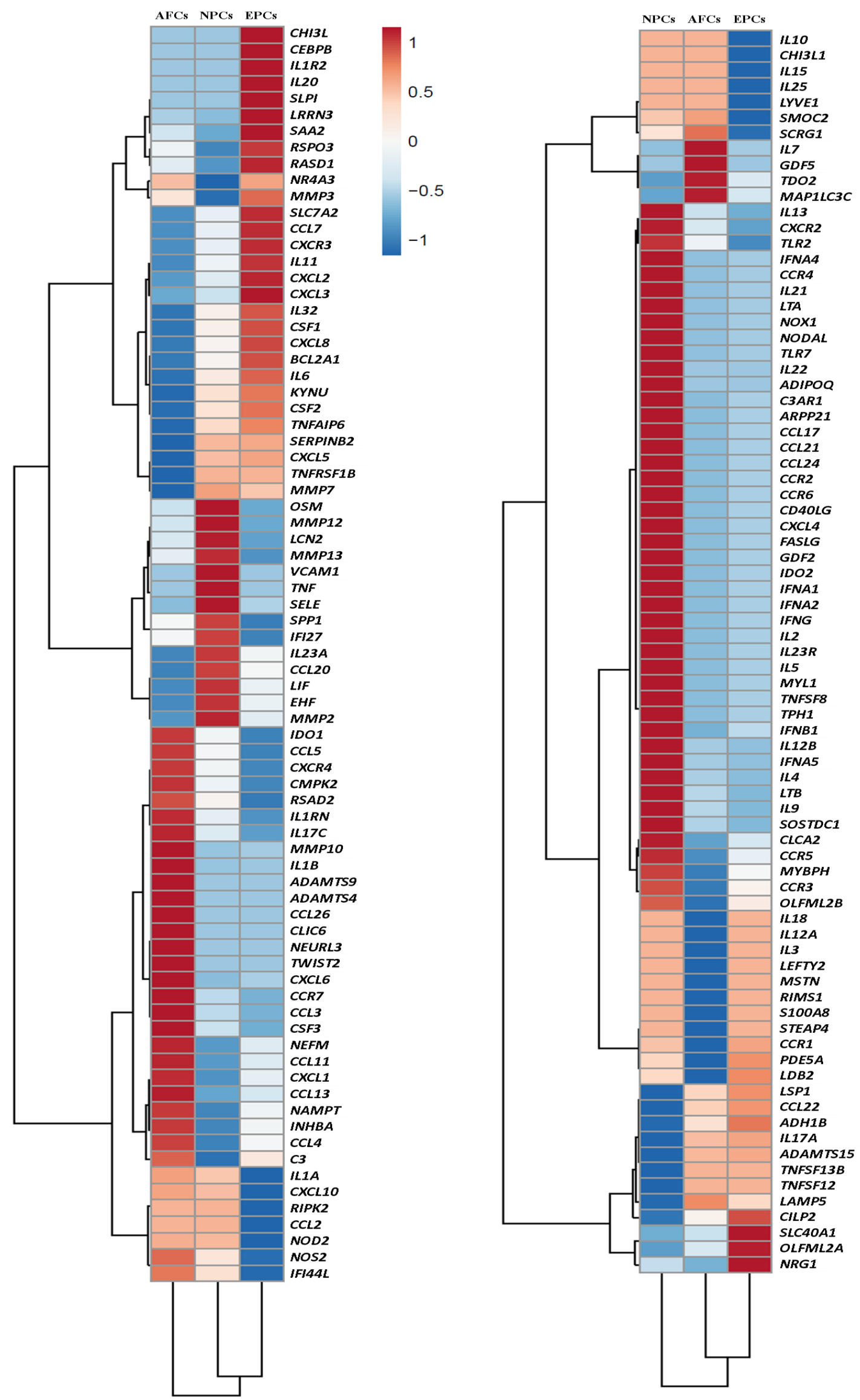

Fig. 4. Heat maps and clustering representing the inflammation-related genes modulated by IL-1 $\beta$ treatment. (a) Upregulated ( $\left.\mathrm{Fc}_{\mathrm{c}} \geq+2\right)$ and (b) downregulated ( $\left.\mathrm{Fc}_{\mathrm{c}} \leq-2\right)$ genes $(n=4)$. 
Table 1a. Upregulated or downregulated inflammation-related genes after IL-1 $\beta$ treatment with Fc $\geq+2$ or $\leq-2$ in the different cell populations; (-) no differences.

\begin{tabular}{|c|c|c|c|}
\hline Gene & Fc NPCs & Fc AFCs & Fc EPCs \\
\hline ADAMTS15 & -12.8 & -7.1 & -6.8 \\
\hline ADAMTS4 & - & 2.6 & - \\
\hline ADAMTS9 & - & 2.3 & - \\
\hline$A D H 1 B$ & -28.2 & -13.5 & -8.0 \\
\hline$A D I P O Q$ & - & -2.3 & -2.3 \\
\hline ARPP21 & - & -2.4 & -2.2 \\
\hline BCL2A1 & 3.2 & 2.6 & 3.7 \\
\hline C3 & 4.3 & 6.9 & 6.0 \\
\hline C3AR1 & - & -2.4 & -2.2 \\
\hline CCL11 & - & 10.4 & 3.8 \\
\hline CCL13 & - & 21.8 & 5.8 \\
\hline CCL17 & - & -2.4 & -2.2 \\
\hline CCL2 & 9.5 & 9.5 & 7.7 \\
\hline CCL20 & 1098.9 & 390.3 & 734.1 \\
\hline CCL21 & - & -2.4 & -2.2 \\
\hline CCL22 & -4.2 & -2.5 & -2.2 \\
\hline CCL24 & - & -2.4 & -2.2 \\
\hline CCL26 & - & 4.0 & - \\
\hline CCL3 & 13.4 & 16.5 & 12.9 \\
\hline CCL4 & - & 3.5 & 2.2 \\
\hline CCL5 & 93.2 & 148.0 & 45.2 \\
\hline CCL7 & 5.7 & 5.2 & 6.5 \\
\hline CCR1 & -4.0 & -13.7 & -3.2 \\
\hline CCR2 & - & -2.4 & -2.2 \\
\hline CCR3 & - & -6.6 & -2.4 \\
\hline CCR4 & - & -2.4 & -2.3 \\
\hline CCR5 & - & -4.2 & -2.2 \\
\hline CCR6 & - & -2.4 & -2.2 \\
\hline CCR7 & 5.5 & 11.9 & 4.5 \\
\hline CD40LG & - & -2.4 & -2.2 \\
\hline CEBPB & - & - & 2 \\
\hline CHI3L1 & - & - & -2.2 \\
\hline CHI3L2 & - & - & 2.2 \\
\hline CILP2 & -6.4 & -2.2 & - \\
\hline CLCA2 & - & -3.1 & -2.1 \\
\hline CLIC6 & - & 3.0 & - \\
\hline СMРК2 & 2.2 & 3.8 & - \\
\hline CSF1 & 3.2 & 2.4 & 3.8 \\
\hline CSF2 & 61.6 & 12.1 & 82.7 \\
\hline CSF3 & 25.7 & 77.0 & 15.5 \\
\hline CXCL1 & 102.5 & 162.4 & 124.1 \\
\hline CXCL10 & 12.2 & 12.9 & 2.7 \\
\hline CXCL2 & 33.8 & 22.2 & 59.7 \\
\hline CXCL3 & 59.5 & 47.3 & 114.0 \\
\hline CXCL4 & - & -2.4 & -2.2 \\
\hline CXCL5 & 17.3 & 9.4 & 17.9 \\
\hline CXCL6 & 442.9 & 1702.1 & 512.0 \\
\hline CXCL8 & 501.9 & 438.6 & 555.9 \\
\hline CXCL9 & - & 5.0 & -2.2 \\
\hline CXCR2 & - & -2.3 & -3.4 \\
\hline CXCR3 & 3.2 & 2.5 & 4.3 \\
\hline CXCR4 & 17.2 & 33.2 & 4.2 \\
\hline EHF & 44.4 & 8.5 & 23.3 \\
\hline FASLG & - & -2.4 & -2.2 \\
\hline GDF2 & - & -2.4 & -2.2 \\
\hline
\end{tabular}


Table 1b. Upregulated or downregulated inflammation-related genes after IL-1 $\beta$ treatment with Fc $\geq+2$ or $\leq-2$ in the different cell populations; (-) no differences.

\begin{tabular}{|c|c|c|c|}
\hline Gene & Fc NPCs & Fc AFCs & Fc EPCs \\
\hline GDF5 & -3.0 & -2.5 & -3.0 \\
\hline IDO1 & 17.7 & 32.6 & 4.8 \\
\hline IDO2 & - & -2.4 & -2.2 \\
\hline IFI27 & 14.2 & 10.5 & 7.1 \\
\hline IFI44L & 9.2 & 12.3 & - \\
\hline IFNA1 & - & -2.4 & -2.2 \\
\hline IFNA2 & - & -2.4 & -2.2 \\
\hline IFNA4 & - & -2.4 & -2.3 \\
\hline IFNA5 & - & -2.3 & -2.4 \\
\hline IFNB1 & - & -2.8 & -2.3 \\
\hline IFNG & - & -2.4 & -2.2 \\
\hline IL10 & - & - & -2.8 \\
\hline IL11 & 30.4 & 26.2 & 36.3 \\
\hline IL12A & - & -2.4 & - \\
\hline IL12B & - & -2.4 & -2.5 \\
\hline IL13 & - & -2.2 & -2.9 \\
\hline IL15 & - & - & -2.1 \\
\hline IL17A & -5.4 & -2.4 & -2.2 \\
\hline IL17C & 4.5 & 6.0 & 3.9 \\
\hline IL18 & - & -3.8 & - \\
\hline$I L 1 A$ & 14.4 & 15.5 & 5.0 \\
\hline IL1B & 5.3 & 10.9 & 5.4 \\
\hline IL1R2 & - & - & 2.8 \\
\hline IL1RN & 8.4 & 15.1 & 4.6 \\
\hline IL2 & - & -2.4 & -2.2 \\
\hline IL20 & - & - & 2.2 \\
\hline IL21 & - & -2.4 & -2.3 \\
\hline IL22 & - & -2.4 & -2.4 \\
\hline IL23A & 368.2 & 153.1 & 251.6 \\
\hline IL23R & - & -2.4 & -2.2 \\
\hline IL25 & - & - & -3.1 \\
\hline IL3 & - & -2.4 & - \\
\hline IL32 & 2.7 & - & 3.9 \\
\hline IL4 & - & -2.4 & -2.6 \\
\hline IL5 & - & -2.4 & -2.2 \\
\hline IL6 & 66.5 & 46.3 & 78.0 \\
\hline IL7 & -3.1 & - & -2.9 \\
\hline IL9 & - & -2.4 & -2.8 \\
\hline INHBA & 3.1 & 4.2 & 3.6 \\
\hline$K Y N U$ & 16.6 & 13.8 & 17.7 \\
\hline LAMP5 & -9.1 & -5.7 & -6.4 \\
\hline LCN2 & 433.5 & 228.0 & 158.7 \\
\hline$L D B 2$ & -6.0 & -11.1 & -4.7 \\
\hline LEFTY2 & - & -2.6 & - \\
\hline LIF & 4.2 & 3.7 & 3.9 \\
\hline LRRN3 & 4 & 4.2 & 7.6 \\
\hline LSP1 & -5.3 & -3.9 & -3.6 \\
\hline$L T A$ & - & -2.4 & -2.3 \\
\hline$L T B$ & - & -2.4 & -2.8 \\
\hline LYVE1 & - & - & -2.4 \\
\hline MAP1LC3C & -21.5 & -17.2 & -20.5 \\
\hline MMP10 & 11.5 & 19.2 & 11.7 \\
\hline MMP12 & 142.4 & 95.3 & 83.4 \\
\hline MMP13 & 24.8 & 13.3 & 7.2 \\
\hline MMP2 & 3 & 2.4 & 2.6 \\
\hline MMP3 & 65.1 & 84.5 & 93.6 \\
\hline
\end{tabular}


Table 1c. Upregulated or downregulated inflammation-related genes after IL-1 $\beta$ treatment with Fc $\geq+2$ or $\leq-2$ in the different cell populations; (-) no differences.

\begin{tabular}{|c|c|c|c|}
\hline Gene & Fc NPCs & Fc AFCs & Fc EPCs \\
\hline MMP7 & 5.7 & 2.8 & 5.4 \\
\hline MSTN & - & -2.6 & - \\
\hline МYВРН & -2.7 & -2.9 & -2.8 \\
\hline MYL1 & - & -2.4 & -2.2 \\
\hline NAMPT & 4.6 & 5.5 & 5.0 \\
\hline NEFM & - & 6.9 & 2.8 \\
\hline NEURL3 & - & 2.6 & - \\
\hline NOD2 & 20 & 20.2 & 12.4 \\
\hline NODAL & - & -2.5 & -2.4 \\
\hline NOS2 & 40.4 & 49.9 & 20.0 \\
\hline NOX1 & - & -2.4 & -2.3 \\
\hline$N R 4 A 3$ & - & 2.3 & 2.4 \\
\hline NRG1 & -2.5 & -3.1 & - \\
\hline OLFML2A & -6.8 & -6.3 & -4.9 \\
\hline OLFML2B & -2.1 & -3.9 & -2.8 \\
\hline OSM & 7.7 & 3.7 & 2.8 \\
\hline PDE5A & -5.6 & -7.6 & -5.2 \\
\hline RASD1 & 2.6 & 2.7 & 2.9 \\
\hline RIMS1 & -2.3 & -2.4 & -2.3 \\
\hline RIPK2 & 2.1 & 2.1 & - \\
\hline RSAD2 & 4.3 & 6.1 & 2.1 \\
\hline RSPO3 & 5.1 & 6.2 & 7.6 \\
\hline S100A8 & - & -2.4 & - \\
\hline$S A A 2$ & 19.5 & 26.2 & 53.3 \\
\hline SCRG1 & -3.1 & -2.8 & -3.8 \\
\hline SELE & 32.8 & 8.0 & 9.9 \\
\hline SERPINB2 & 3.1 & - & 3.2 \\
\hline SLC40A1 & -6.0 & -5.9 & -5.4 \\
\hline SLC7A2 & 51.3 & 49.8 & 53.7 \\
\hline SLPI & - & - & 2.1 \\
\hline SMOC2 & -3.0 & -2.8 & -4.8 \\
\hline SOSTDC1 & - & -2.4 & -2.7 \\
\hline SPP1 & 2.9 & 2.6 & 2.3 \\
\hline STEAP4 & - & -5.9 & - \\
\hline TDO2 & -4.9 & - & -3.3 \\
\hline TLR2 & - & -2.4 & -4.8 \\
\hline TLR7 & - & -2.3 & -2.2 \\
\hline TNF & 3.4 & - & - \\
\hline TNFAIP6 & 68.4 & 21.5 & 81.7 \\
\hline TNFRSF1B & 3.4 & - & 3.4 \\
\hline TNFSF12 & -2.2 & - & - \\
\hline TNFSF13B & -2.2 & - & - \\
\hline TNFSF8 & - & -2.4 & -2.2 \\
\hline TPH1 & - & -2.4 & -2.2 \\
\hline TWIST2 & - & 3.0 & - \\
\hline VCAM1 & 2.5 & - & - \\
\hline
\end{tabular}

the pro-inflammatory and pro-apoptotic LTA, the proapoptotic FASLG, the toll receptor signalling TLR2 and TLR7, the metabolic ADIPOQ, IDO2, NOX1, SOSTDC1 and TPH1, the TGF- $\beta$ signalling GDF2 were also downregulated after inflammation. Moreover, downregulation of IFNB1 and MYL1, belonging to the muscle contraction pathway, and of ARPP21 and CLCA2 was observed. NPCs and AFCs presented a common downregulation of NRG1, involved in the
EGF receptor pathway, and of CILP2; NPCs and EPCs shared the downregulation of TDO2 and the pro-inflammatory IL7. An exclusive downregulation was observed in NPCs of the pro-inflammatory and pro-apoptotic TNFSF12 and TNFSF13B and of PDGFB; in AFCs of the pro-inflammatory IL18, S100A8 and STEAP4 and of IL3, IL12A, MSTN and LEFTY2. EPCs showed a selective downregulation of the pro-inflammatory CXCL9, IL15, IL25, of the 
Table 2. Upregulated or downregulated angiogenesis-related genes after IL-1 $\beta$ treatment with Fc $\geq+2$ or $\leq-2$ in the different cell populations; (-) no differences.

\begin{tabular}{|c|c|c|c|}
\hline Gene & Fc NPCs & Fc AFCs & Fc EPCs \\
\hline ADGRB1 & -3.1 & -2.7 & -2.4 \\
\hline ANGPT1 & 3.1 & 4.1 & 5.0 \\
\hline ANGPT2 & - & -2.3 & -2.2 \\
\hline ANGPTL1 & - & 2.6 & - \\
\hline CD55 & 7.9 & 5.9 & 8.8 \\
\hline CDH5 & - & -2.9 & -2.2 \\
\hline$C H G A$ & - & -2.4 & -2.3 \\
\hline CNMD & -3.0 & -3.1 & -2.2 \\
\hline COL4A3 & - & -2.4 & -2.2 \\
\hline CXCL11 & - & -2.3 & -2.2 \\
\hline CXCL12 & -3.8 & -2.9 & -2.8 \\
\hline CXCL13 & - & -2.4 & -2.3 \\
\hline EREG & 14.0 & 8.4 & 12.0 \\
\hline F3 & 2.5 & 2.4 & 2.9 \\
\hline FGF2 & - & 2.1 & - \\
\hline FGFBP1 & 9.3 & 16.2 & 7.5 \\
\hline FGFR3 & -2.2 & - & -2.2 \\
\hline$F S T$ & 2.3 & 2.2 & 2.4 \\
\hline$G R P$ & - & -2.4 & - \\
\hline IL17F & - & -2.4 & -2.2 \\
\hline KITLG & 2.3 & - & 2.3 \\
\hline LEP & -2.1 & - & - \\
\hline NOS3 & -2.9 & - & -2.8 \\
\hline NOTCH4 & - & 2.7 & - \\
\hline NRP1 & - & -2.2 & - \\
\hline NRP2 & 2.9 & 3.4 & 2.7 \\
\hline PECAM1 & - & - & -11.8 \\
\hline$P L G$ & - & -2.5 & -2.4 \\
\hline PРBP & - & -2.4 & -2.2 \\
\hline PROK1 & -3.8 & - & -3.5 \\
\hline PROK2 & - & -2.4 & -2.2 \\
\hline PTGS1 & 4.3 & 3.7 & 4.6 \\
\hline RNH1 & -2.5 & -2.8 & -3.1 \\
\hline SERPINC1 & - & -2.4 & - \\
\hline SPINK5 & -2.9 & -2.3 & -2.5 \\
\hline TGFB2 & -2.2 & - & -2.9 \\
\hline TGFBR1 & 3.0 & 2.6 & 3.0 \\
\hline TYMP & 2.2 & 2.6 & 2.3 \\
\hline VEGFB & - & -2.4 & - \\
\hline VEGFD & - & -2.4 & -2.3 \\
\hline
\end{tabular}

anti-inflammatory IL10, of the catabolic CHI3L1 and of the metabolic LYVE1.

Heat maps and clustering showed that NPCs and EPCs shared a similar entity of upregulated (Fig. 4a) whereas AFCs and EPCs of downregulated (Fig. 4b) inflammation-related genes after IL-1 $\beta$ treatment. Table $1 \mathbf{a}, \mathbf{b}, \mathbf{c}$ report $\mathrm{Fc}_{\mathrm{C}} \geq+2$ or $\leq-2$.

Angiogenesis-related genes

After IL-1 $\beta$ treatment, 40 genes were modulated (14 upregulated and 26 downregulated), 9 of which involved in inhibition of angiogenesis, 27 in promotion of angiogenesis and 4 with an unclear function in angiogenesis. All 9 genes with an inhibitory role were downregulated by the treatment with IL-13: ADGRB1, CNMD, RNH1 and SPINK5 in all three cell populations; SERPINC1 only in AFCs; ANGPT2, CHGA, COL4A3 and IL17F in AFCs and EPCs. Among the pro-angiogenic, ANGPT1, CD55, EREG, FGFBP1 and PTGS1 were highly upregulated $\left(3.1 \leq \mathrm{FC}_{\mathrm{C}} \leq 16.2\right)$ as well as F3, FST, NRP2, TGFBR1 and TYMP, even if to a lesser extent $(2.2 \leq \mathrm{FC} \leq 3.4)$, in all the cell populations. Moreover, ANGPT1, FGF2 and NOTCH4 were upregulated only in AFCs. After 
IL-1 $\beta$ treatment, some pro-angiogenic genes such as CXCL12 were downregulated in all analysed cell populations. CDH5, CXCL11, PLG, PROK2 and VEGFD showed the same trend in both AFCs and EPCs, whereas FGFR3, LEP, NOS3 and PROK1 in both NPCs and EPCs. GRP, NRP1 and VEGFB were downregulated only in AFCs and PECAM1 only in EPCs, with the highest downregulation $(\mathrm{FC}=-11.8)$. In Table 2, all modulated genes with their respective Fc are reported.

\section{Growth-factor-related and trophic genes}

After IL-1 $\beta$ treatment, 11 growth factors and trophic genes were modulated, of which 7 were upregulated (FGF7, IGF1, IGFBP4 and IGFBP5 were shared by all cell populations), 3 were downregulated and one (AREG) was both upregulated (EPCs) and downregulated (AFCs). Among the upregulated genes, IGFBP2 was shared by NPCs and AFCs, TGFB3 was shared by NPCs and EPCs, IGF2 was only upregulated in NPCs and $A R E G$ in EPCs. Concerning the downregulated genes, $A R E G$ and CSF1R were downregulated only in AFCs and FGF6 and NTF4 were shared by AFCs and EPCs. In Table 3 , all modulated genes with their respective Fc are reported.

\section{Senescence-related genes}

After IL-1 $\beta$ treatment, 12 senescence-related genes were modulated. All, except for $P P P 2 R 1 B$ that was upregulated, were downregulated. In particular, $B C L 2$ and PPARG were downregulated in all cell populations; EGF, KRAS and PRKCB in AFCs and EPCs; SIRT2 in NPCs and EPCs; CHEK1 only in NPCs; BLM, DCLRE1B, EME1 and PLK1 only in AFCs. In Table 4, all modulated genes with their respective $\mathrm{Fc}$ are reported.

\section{Protein profiling}

In basal condition, the three cell populations showed no differences in the production of inflammatory mediators, whereas this was affected by the presence of IL-1 $\beta$ (Fig. 5a). After IL-1 $\beta$ treatment, all cells released more pro-inflammatory ICAM-1 and IL$1 \beta$ and anti-inflammatory IL-11 and GM-CSF. In all cell populations, the anti-inflammatory IL-1Ra levels were higher after the inflammatory stimulus in comparison with basal levels $(p<0.01)$ (Fig. 5b). NPCs showed an increase in the pro-inflammatory IL-8 and IL-6sR, accompanied by a decrease in the anti-inflammatory IL-10. Moreover, AFCs showed increased levels of the pro-inflammatory IL-8, MIP$1-\alpha$ and MIP-1- $\beta$. EPCs were the most responsive cells to IL-1 $\beta$, showing metabolic inhibition characterised by decreased levels of the pro-inflammatory eotaxin-2, IL-3, IL-15, IL-16, IL-17, MCP-1 and PDGF$\mathrm{BB}$ and of the anti-inflammatory IL-10, IL-13, sTNF-RI and TIMP-2 proteins. The anti-inflammatory IP-10 was increased in both AFCs and EPCs. The protein analysis confirmed the gene expression results for GM-CSF, IL-1 $\beta$, IL-11, IL-15, MCP-2 and MIP-1- $\delta$
Table 3. Upregulated or downregulated growthfactor-related and trophic genes after IL-1 $\beta$ treatment with $\mathrm{Fc}_{\mathrm{C}} \geq+2$ or $\leq-2$ in the different cell populations; (-) no differences.

\begin{tabular}{|c|c|c|c|}
\hline Gene & Fc NPCs & Fc AFCs & Fc EPCs \\
\hline AREG & - & -2.3 & 3.5 \\
\hline CSF1R & - & -2.4 & - \\
\hline FGF6 & - & -2.4 & -2.3 \\
\hline FGF7 & 2.8 & 2.6 & 3.2 \\
\hline IGF1 & 6.5 & 20.9 & 5.5 \\
\hline IGF2 & 2.4 & - & - \\
\hline IGFBP2 & 2.5 & 6.9 & - \\
\hline IGFBP4 & 2.3 & 3.3 & 2.3 \\
\hline IGFBP5 & 2.4 & 2.5 & 4 \\
\hline NTF4 & - & -2.4 & -2.5 \\
\hline TGFB3 & 2.5 & - & 2.3 \\
\hline
\end{tabular}

in all cell populations, for IL-8 in NPCs and AFCs, for IP-10 in AFCs and EPCs, for MIP-1- $\alpha$ and MIP$1-\beta$ in AFCs, for IL-10, IL-13, IL-17 and eotaxin- 2 in EPCs. Despite the upregulation or downregulation of the gene expression, no significant changes were observed in the release of most of the analysed proteins. No changes in ICAM1 expression, but an increase in protein release in all cell populations was observed. Finally, no changes were observed in the expression of IL16, sTNF-RI and PDGF-BB in EPCs and IL10 in NPCs despite a decreased release of these proteins. The comparison between gene expression and protein release is reported in Table 5.

\section{Discussion}

The findings of the present study showed that AFCs and EPCs were more molecularly responsive to IL-1 $\beta$ treatment than NPCs. In particular, AFCs showed the largest release of pro-inflammatory-related proteins, whereas EPCs showed the greatest anti-inflammatory ability.

As far as it can be ascertained, the present is the first study comparing side-by-side the molecular profile of NPCs, AFCs and EPCs in response to in vitro inflammation. The responses include the release of stemness, pro/anti-inflammatory, angiogenic and trophic factors and the expression of genes participating in multiple signalling cascades and biological processes. The inflammatory stimulus induced a marked downregulation (5.7 times more than the upregulated genes) of the stemness genes. All cell types showed comparable numbers of upregulated stemness genes, whereas AFCs and EPCs showed a slightly larger number of downregulated genes in comparison with NPCs, sharing with EPCs, on the other hand, a similar entity of modulation.

Recently, the expression of a very large panel of genes in IVD- and EP-expanded cells derived from 
Table 4. Upregulated or downregulated senescence-related genes after IL-1 $\beta$ treatment with Fc $\geq+2$ or $\leq-2$ in the different cell populations; (-) no differences.

\begin{tabular}{|c|c|c|c|}
\hline Gene & Fc NPCs & Fc AFCs & Fc EPCs \\
\hline BCL2 & -2.6 & -2.5 & -3.1 \\
\hline BLM & - & -2.3 & - \\
\hline CHEK1 & -2.1 & - & - \\
\hline DCLRE1B & - & -2.3 & - \\
\hline EGF & - & -2.3 & -2.3 \\
\hline EME1 & - & -2.3 & - \\
\hline KRAS & - & -2.4 & -2.2 \\
\hline PLK1 & - & -2.1 & - \\
\hline PPARG & -4.2 & -4.0 & -3.8 \\
\hline PPP2R1B & - & - & 2.8 \\
\hline PRKCB & - & -2.4 & -2.2 \\
\hline SIRT2 & -2.1 & - & -2.1 \\
\hline
\end{tabular}

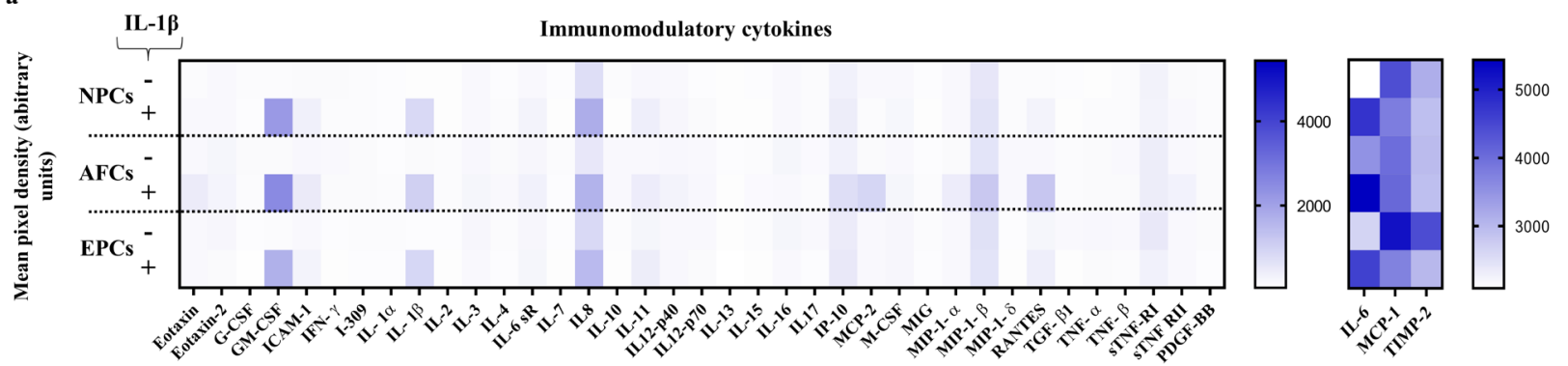

\begin{tabular}{|c|c|c|}
\hline Cell type & $\begin{array}{c}\text { Significantly }(p<0.05) \\
\text { upregulated post-IL-1 } \beta \\
\text { stimulation }\end{array}$ & $\begin{array}{c}\text { Significantly }(p<0.05) \\
\text { downregulated post-IL-1 } \beta \\
\text { stimulation }\end{array}$ \\
\hline NPCs & $\begin{array}{c}\text { GM-CSF, ICAM-1, IL-1 } \beta, \\
\text { IL-6sR, IL-8, IL-11 }\end{array}$ & IL-10 \\
\hline AFCs & $\begin{array}{c}\text { GM-CSF, ICAM-1, IL-1 } \beta, \\
\text { IL-8, IL-11, IP-10, MIP-1- } \alpha, \\
\text { MIP-1- } \beta\end{array}$ & - \\
\hline EPCs & $\begin{array}{c}\text { GM-CSF, ICAM-1, IL-1 } \beta, \\
\text { IL-11, IP-10 }\end{array}$ & $\begin{array}{c}\text { Eotaxin-2, IL-3, IL-10, IL-13, } \\
\text { IL-15, IL-16, IL-17, MCP-1, } \\
\text { sTNF-RI, PDGF-BB, TIMP-2 }\end{array}$ \\
\hline
\end{tabular}

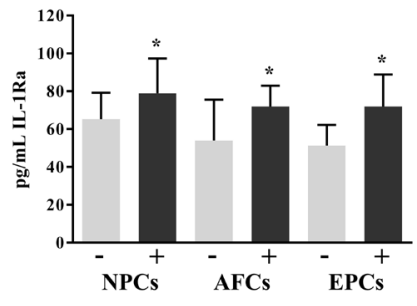

Fig. 5. Protein secretion in conditioned media obtained from NPCs, AFCs and EPCs at basal (-) and poststimulation with IL-1 $\beta$ (+). (a) Secretome multiplex analysis of immunomodulatory cytokines presented as overall heat maps of mean pixel intensity. Table shows significantly upregulated and downregulated molecules after IL-1 $\beta$ stimulation $(n=4)$. (b) ELISA assay of IL-1Ra release. ${ }^{*} p \leq 0.05$ indicates IL-1 $\beta$ treated vs. basal, in each cell populations $(n=8)$.

the same donors has been evaluated. AFCs present the largest number of selectively highly expressed stemness and chondrogenic/tissue specific genes (De Luca et al., 2020), therefore representing the most promising IVD cell population for the treatment of IVD degeneration. Differently from what observed in basal conditions, the results of the present study did not provide a strong indication about the identification of AFCs as having the greatest stemness potential in the presence of an inflammatory stimulus.

Interestingly, the trophic IGF1, marker of notochordal cells (Peck et al., 2017), appeared upregulated in the presence of IL-1 $\beta$, especially in
AFCs $(F c=20.9)$. Previous in vitro and in vivo studies have demonstrated that IGF-1 exerts anabolic, proliferative and anti-apoptotic effects on disc cells (Day et al., 2005; Masuda and An, 2006; Masuda et al., 2004; Osada et al., 1996; Pratsinis and Kletsas, 2007; Sakai, 2008). These data suggest a tissue protective response to inflammation. In addition, in the present study, an upregulation of IGF2, a competitor of IGF1 for the binding with IGF-R1 (Travascio et al., 2014; Zhang et al., 2013a), was observed only in NPCs. A concomitant upregulation of IGFBP2 in NPCs and AFCs and of IGFBP4 and IGFBP5 in all the analysed cells was observed. This suggests an attempt of these 
Table 5. Protein array and expression of their encoding genes; increase (+), decrease (-) or no variation (=).

\begin{tabular}{|c|c|c|c|c|c|c|c|}
\hline \multirow[b]{2}{*}{ Gene } & \multirow[b]{2}{*}{ Protein } & \multicolumn{2}{|c|}{ NPCs } & \multicolumn{2}{|c|}{ AFCs } & \multicolumn{2}{|c|}{ EPCs } \\
\hline & & Gene & Protein & Gene & Protein & Gene & Protein \\
\hline CCL2 & MCP-1 & + & $=$ & + & $=$ & + & - \\
\hline CCL3 & MIP-1- $\alpha$ & + & $=$ & + & + & + & $=$ \\
\hline CCL4 & MIP-1- $\beta$ & $=$ & $=$ & + & + & + & $=$ \\
\hline CCL5 & RANTES & + & $=$ & + & $=$ & + & $=$ \\
\hline CCL8 & MCP-2 & $=$ & $=$ & $=$ & $=$ & $=$ & $=$ \\
\hline CCL11 & Eotaxin & $=$ & $=$ & + & $=$ & + & $=$ \\
\hline CCL15 & MIP-1- $\delta$ & $=$ & $=$ & $=$ & $=$ & $=$ & $=$ \\
\hline CSF1 & M-CSF & + & $=$ & + & $=$ & + & $=$ \\
\hline CXCL8 & IL-8 & + & + & + & + & + & $=$ \\
\hline CXCL9 & MIG & $=$ & $=$ & - & $=$ & - & $=$ \\
\hline CXCL10 & IP-10 & + & $=$ & + & + & + & + \\
\hline ICAM1 & ICAM-1 & $=$ & + & $=$ & + & $=$ & + \\
\hline IFNG & IFN $\gamma$ & $=$ & $=$ & - & $=$ & - & $=$ \\
\hline IL1A & IL-1 $\alpha$ & + & $=$ & + & $=$ & + & $=$ \\
\hline IL1B & IL-1 $\beta$ & + & + & + & + & + & + \\
\hline IL2 & IL-2 & $=$ & $=$ & - & $=$ & - & $=$ \\
\hline IL3 & IL-3 & $=$ & $=$ & - & $=$ & $=$ & - \\
\hline IL6 & IL-6 & + & $=$ & + & $=$ & + & $=$ \\
\hline IL7 & IL-7 & - & $=$ & $=$ & $=$ & - & $=$ \\
\hline IL11 & IL-11 & + & + & + & + & + & + \\
\hline IL15 & IL-15 & $=$ & $=$ & $=$ & $=$ & - & - \\
\hline IL16 & IL-16 & $=$ & $=$ & $=$ & $=$ & $=$ & - \\
\hline IL17A & IL-17 & - & $=$ & - & $=$ & - & - \\
\hline$T N F$ & TNF- $\alpha$ & + & $=$ & $=$ & $=$ & $=$ & $=$ \\
\hline LTA & TNF- $\beta$ & $=$ & $=$ & - & $=$ & - & $=$ \\
\hline GSF3 & G-CSF & + & $=$ & + & $=$ & + & $=$ \\
\hline IL4 & IL-4 & $=$ & $=$ & - & $=$ & - & $=$ \\
\hline IL10 & IL-10 & $=$ & - & $=$ & $=$ & - & - \\
\hline IL13 & IL-13 & $=$ & $=$ & - & $=$ & - & - \\
\hline TNFRSF1A & sTNFRI & $=$ & $=$ & $=$ & $=$ & $=$ & - \\
\hline TNFRSF1B & sTNFRII & + & $=$ & $=$ & $=$ & + & $=$ \\
\hline PDGFB & PDGF-BB & - & $=$ & $=$ & $=$ & $=$ & - \\
\hline IL12B & IL12p40/IL12p70 & $=$ & $=$ & - & $=$ & - & $=$ \\
\hline CCL24 & Eotaxin2 & $=$ & $=$ & - & $=$ & - & - \\
\hline CSF2 & GM-CSF & + & + & + & + & + & + \\
\hline
\end{tabular}

cells to promote the increase of IGF-1 and IGF-2 halflife, mediated by the binding with IGFBPs (Asfour et al., 2015; Elmasry et al., 2016; Zhang et al., 2013a).

ECM disruption is a major hallmark of IVD degeneration and many studies have demonstrated that degradation enzymes such as MMPs and ADAMTS are upregulated in pathological discs (Wang et al., 2015). After IL-1 $\beta$ treatment, all cell populations showed an upregulation of genes coding for several MMPs involved in gelatine, collagens, proteoglycans, laminin, fibronectin and elastin degradation. In particular, despite the physiological role of MMPs in repair and remodelling and their low expression in normal tissue, the catabolic effect of inflammation was demonstrated through the upregulation of $M M P 1, M M P 2, M M P 3, M M P 10$ and $M M P 12$, confirming what observed in IVD pathological tissues (Bachmeier et al., 2009; Canbay et al., 2013; Gruber et al., 2014b; Richardson et al., 2009; Tang et al., 2014; Xu et al., 2014a; Xu et al., 2014b).

Along with MMPs, ADAMTS contribute to the physiological disc ECM turnover. In the present study, IL-1 $\beta$ induced an upregulation of ADAMTS4, a highly active aggrecanase-1 (Gendron et al., 2007), and ADAMTS9 in AFCs. ADAMTS4 is significantly increased in human degenerated IVD tissue in comparison with normal tissue (Pockert et al., 2009; Zhang et al., 2012) and IL-1 $\beta$ promotes its upregulation in NPCs (Wang et al., 2011). In contrast, a downregulation of ADAMTS15, generally increased in human degenerated IVD tissue (Pockert et al., 2009; Zhang et al., 2012), was observed in the analysed cell populations. The general catabolic switch induced by IL-1 $\beta$ was not balanced by a concomitant upregulation of TIMP1, TIMP2 and TIMP3. Nevertheless, a strong upregulation of TNFAIP6 $(21.5<\mathrm{Fc}<81.7)$ was 
observed in all cell types. The TSG-6 protein encoded by this gene is not normally present in healthy adult tissues, but it is induced by pro-inflammatory cytokines such as IL-1 $\beta$ (Milner and Day, 2003) and plays a protective role against cartilage matrix degradation and inflammation (Glant et al., 2002; Wisniewski and Vilcek, 1997). Moreover, a colocalisation of IL-1 $\beta$ and TSG-6 is observed in normal and degenerated IVD tissues (Roberts et al., 2005), suggesting this interplay also in the disc. The study results showed an anti-inflammatory and anabolic response of all the analysed disc cells mediated by TSG- 6 in inflamed conditions. TSG- 6 is also able to inhibit neutrophil migration (Getting et al., 2002) and likely it counteracted the upregulation of chemokine ligands, particularly CXCL1, CXCL2, CXCL3, CXCL5, and even more CXCL6 and CXCL8 after IL- $1 \beta$ stimulation in the three cell populations. The expression of CXCR2, receptor of these ligands, was slightly downregulated in AFCs and EPCs, indicating an attempt to inhibit the effect of these chemokines on these cells. In general, considering the modulation of the inflammatory genes by IL- $1 \beta$, there was a balance between the number of upregulated or downregulated genes, mainly encoding for cytokines, chemokines and their receptor or antagonist, with a very similar behaviour shared by AFCs and EPCs. Moreover, a similar entity of upregulation was shown by NPCs and EPCs, whereas AFCs and EPCs shared a similar modulation of downregulated genes.

CCL2, a chemoattractant for monocytes and basophils, together with its receptors CCR2 or CCR4, plays a role in the induction of the inflammatory process in herniated discs, as demonstrated in a mouse model of IVD degeneration induced by TNF- $\alpha$ (Nakawaki et al., 2019), and it is expressed by NPCs as a protein related to the histological degenerative tissue changes (Phillips et al., 2013). After IL-1 $\beta$ treatment, an overexpression of CCL2 $\left(7.7<\mathrm{FC}_{\mathrm{C}}<9.5\right)$ in all cell populations was observed in agreement with an increased expression of this cytokine, as previously shown in human AFCs (Gruber et al., 2015). The level of the released MCP-1, encoded by CCL2, decreased in EPCs after IL- $1 \beta$ treatment, probably due to a negative feedback control promoted by these cells, as recently demonstrated for murine IVD cells exposed to TNF $\alpha$ (Nakawaki et al., 2019). Monocytes recruitment/mobilisation is also obtained from the binding of CCL7 with its receptors CCR2 or CCR3 (Sokol and Luster, 2015). NPCs are a source of CCL7, whose release increases along with IVD degeneration grade (Phillips et al., 2013). In the present study, an upregulation of CCL7 was observed in all cell populations, suggesting a possible monocyte recruitment in inflamed discs. A concomitant downregulation of CCR2, CCR3 and CCR4 could be ascribed again to the attempt to limit the effect of CCL2 and CCL7 in AFCs and EPCs.

Another chemoattractant is CCL3; through its receptors CCR1 and CCR5, this chemokine induces white blood cell recruitment and promotes IVD inflammation and degeneration (Liu et al., 2015; Wang et al., 2013). After the pro-inflammatory stimulation, a higher expression of CCL3 $(13.4<\mathrm{FC}<16.5)$ was observed in all IVD cells as well as a downregulation of CCR1 and CCR5 in AFCs and EPCs, probably to counteract the effect of CCL3 on disc cells. Other two chemoattractant of white blood cells were upregulated by the inflammatory stimulus, CCL4 in AFCs and EPCs and CCL5 in all the cell populations $(45.2<\mathrm{Fc}<148)$. CCL5 is significantly high in disc cells derived from patients with severe disc degeneration (Gruber et al., 2014a; Weber et al., 2015) and its expression levels correlate with the IVD degenerative grade (Gruber et al., 2014a). CCR1, CCR3 and CCR5, receptors of CCL5 (Gruber et al., 2015; Sokol and Luster, 2015) and CCL4, were all downregulated; in particular, CCR1 in all cell populations, CCR3 and CCR5 in AFCs and EPCs, highlighting that AFCs and EPCs share a similar behaviour to counteract this signalling. In contrast, IL- $1 \beta$ treatment induced upregulation of CXCL10, a chemokine promoting a Th1-orienting (pro-inflammatory) attitude (Romagnani et al., 2005), in all the analysed cell populations and downregulation of CXCL4 (Romagnani et al., 2005) and CCL17 in AFCs and EPCs and of CCL22 in all cell populations (Sokol and Luster, 2015). All these chemokines are involved in the Th2 (anti-inflammatory) response. The concomitant upregulation in AFCs and EPCs of CXCR3, receptor of CXCL10, suggests a pro-inflammatory behaviour and probably is responsible for the downregulation of IL-4, IL-5 and IL-13 observed in the same populations (Romagnani et al., 2005). Taken together, these results suggest a promotion, by all analysed cells, of white blood cells recruitment and of a pro-inflammatory switch induction after IL-1 $\beta$ stimulation.

CCL20 (390.3 < FC < 1,098.9), involved in Th17 response (Tesmer et al., 2008), was found among the highest upregulated genes in all cell populations, along with a downregulation of its receptor CCR6 and of the pro-inflammatory IL17A in AFCs and EPCs, likely an attempt of these cells to limit selfdetrimental effects of CCL20-mediated signalling. CCL20 production is observed in degenerated and cultured NPCs and its release further increases after IL-17A or TNF- $\alpha$ stimulation (Zhang et al., 2013b). Interestingly, the same authors reported the expression of CCR6 in PBMCs derived from patients with IVD degeneration and of IL-17A in pathologic IVD tissues (Shamji et al., 2010; Zhang et al., 2013b).

Inflammatory cytokines such as TNF $\alpha$, IL-6 and in particular IL-1 $\beta$ affect matrix metabolism and apoptosis of IVD cells, causing disc degeneration (Kalb et al., 2012; Wuertz and Haglund, 2013). In the presence of IL-1 $\beta$, an upregulation of TNF in NPCs and of IL-1 $\beta$ (both at gene and protein level) and IL6 $(46.3<\mathrm{FC}<78.0)$ in all cell types was observed, probably depending on a positive feedback loop created by IL-1 $\beta$ treatment (Jimbo et al., 2005). In this regard, all three cell populations showed a significant upregulation of IL-1Ra at the gene and 
protein level aimed to counteract IL-1 $\beta$-mediated inflammation. Interestingly, in EPCs there was also a slight upregulation of the expression of the decoy receptor IL1R2, strengthening the anti-inflammatory attitude of these cells towards IL-1 $\beta$. In addition, only in NPCs, the release of IL-6sR increased after IL-1 $\beta$ treatment. Based on what previously reported, although the IL-6/IL-6sR binding induces a proinflammatory response, it also induces, even if to a lesser extent, the upregulation of TIMP1, indicating a protective role in cartilage metabolism (Silacci et al., 1998).

Intriguingly, after IL- $1 \beta$ treatment, in NPCs and EPCs, together with the over-expression of TNF, an upregulation of one of its receptor was observed, TNFRSF1B, also known as TNFR2, that antagonise TNF effects. Moreover, a downregulation of TNF ligands such as TNFSF12 and TNFSF13B (in NPCs) and TNFSF8 (in AFCs and EPCs) was observed, showing an inhibitory overall effect of TNF signalling.

Another well-known marker involved in pathological (Kang et al., 1996) and/or inflamed IVD (Asahara et al., 1996) cells is NO. In agreement with previously reported upregulation of iNOS and NO in NPCs after IL-1 $\beta$ treatment (Bai et al., 2019), after the same inflammatory stimulation, NOS2 was upregulated in all the analysed disc and EP cells. In addition, it was observed in cerebrospinal fluid of patients affected by degenerative lumbar disease (Asahara et al., 1996).

Concerning the angiogenic-related genes evaluated, all the cell populations showed a slight pro-angiogenic behaviour after inflammation, with no inter-population difference. This is in line with what previously reported for human degenerated or inflamed IVDs (Binch et al., 2014).

Between all the analysed cells, AFCs had a slightly senescent attitude, showing a downregulation of DCLRE1B, EME1 and MSH2, related to DNA repair process, of the pro-mitogenic EGF and of PLK1, related to cell cycle control.

One limitation of the present study was the use of only one in vitro model of inflammation. However, IL-1 $\beta$ is the strongest inflammatory stimulus for IVD degeneration (Khan et al., 2017; Johnson et al., 2015; Molinos et al., 2015; Le Maitre et al., 2005; Wuertz and Haglund, 2013). Another limitation was the use of a pool of cells obtained from 4 donors for the gene array. Nevertheless, the expression of the panel of genes was confirmed by protein array (same 4 donors not pooled), ELISA and real-time PCR (same 4 donors and further new 4 donors, not pooled). Finally, functional assays would have been necessary to confirm the role of inflammatory genes in order to ascribe a clear function on the different IVD cells.

\section{Conclusion}

IVD and EP cells were responsive to IL- $1 \beta$, as demonstrated by the massive downregulation of stemness genes and upregulation of proinflammatory and catabolic genes. In the presence of this inflammatory stimulus, all the analysed cell populations attempted to molecularly counteract the degradative process of the matrix. In particular, EPCs showed the most anti-inflammatory response, while AFCs secreted the largest number of proinflammatory mediators. AFCs and EPCs, on the other hand, exhibited a common protective response by repressing the receptors involved in the activation of the signalling mediated by specific chemokines inducing white blood cell recruitment. Molecular targets specific for one or more IVD and EP cell populations in the presence of IL- $1 \beta$ were identified. In particular, in the presence of an inflammatory environment, the anti-inflammatory and anabolic properties of IL-1Ra, IGFs and TSG6 can be exploited to suppress the identified pathological targets upregulated in these cells.

\section{Acknowledgement}

The study was funded by the Italian Ministry of Health, "Ricerca Corrente". Diego Correa and Dimitrios Kouroupis thank the Soffer Family Foundation and the Diabetes Research Institute Foundation (DRIF) for their generous funding support. These funding sources were not involved in any step of the study design, collection, analysis, interpretation of the data or writing of the manuscript.

Diego Correa is a paid consultant of Lipogems USA, LLC. The other authors declare no conflict of interest.

\section{References}

Asahara H, Yokoi I, Tamada T, Kabuto H, Ogawab N, Mori A, Inoue H (1996) Increased cerebrospinal fluid nitrite and nitrate levels in patients with lumbar spondylosis. Res Commun Mol Pathol Pharmacol 91: 77-83.

Asfour S, Travascio F, Elmasry S, de Rivero Vaccari JP (2015) A computational analysis on the implications of age-related changes in the expression of cellular signals on the role of IGF-1 in intervertebral disc homeostasis. J Biomech 48: 332-339.

Bachmeier BE, Nerlich A, Mittermaier N, Weiler C, Lumenta C, Wuertz K, Boos N (2009) Matrix metalloproteinase expression levels suggest distinct enzyme roles during lumbar disc herniation and degeneration. Eur Spine J 18: 1573-1586.

Bai X, Ding W, Yang S, Guo X (2019) Higenamine inhibits IL-1 $\beta$-induced inflammation in human nucleus pulposus cells. Biosci Rep 39. pii: BSR20190857. DOI: 10.1042/BSR20190857.

Binch AL, Cole AA, Breakwell LM, Michael AL, Chiverton N, Cross AK, Le Maitre CL (2014) Expression and regulation of neurotrophic and 
angiogenic factors during human intervertebral disc degeneration. Arthritis Res Ther 16: 416. DOI: 10.1186/s13075-014-0416-1.

Brisby H, Papadimitriou N, Brantsing C, Bergh P, Lindahl A, Barreto Henriksson H (2013) The presence of local mesenchymal progenitor cells in human degenerated intervertebral discs and possibilities to influence these in vitro: a descriptive study in humans. Stem Cells Dev 22: 804-814.

Burke JG, Watson RW, McCormack D, Dowling FE, Walsh MG, Fitzpatrick JM (2002) Spontaneous production of monocyte chemoattractant protein-1 and interleukin- 8 by the human lumbar intervertebral disc. Spine (Phila Pa 1976) 27: 1402-1407.

Canbay S, Turhan N, Bozkurt M, Arda K, Caglar S (2013) Correlation of matrix metalloproteinase-3 expression with patient age, magnetic resonance imaging and histopathological grade in lumbar disc degeneration. Turk Neurosurg 23: 427-433.

Colombini A, Lombardi G, Corsi MM, Banfi G (2008) Pathophysiology of the human intervertebral disc. Int J Biochem Cell Biol 40: 837-842.

Colombini A, Lopa S, Ceriani C, Lovati AB, Croiset SJ, Di Giancamillo A, Lombardi G, Banfi G, Moretti M (2015) In vitro characterization and in vivo behavior of human nucleus pulposus and annulus fibrosus cells in clinical-grade fibrin and collagen-enriched fibrin gels. Tissue Eng Part A 21: 793-802.

Day TF, Guo X, Garrett-Beal L, Yang Y (2005) Wnt/ beta-catenin signaling in mesenchymal progenitors controls osteoblast and chondrocyte differentiation during vertebrate skeletogenesis. Dev Cell 8: 739-750.

De Luca P, Castagnetta M, de Girolamo L, Coco S, Malacarne M, Ragni E, Vigano M, Lugano G, Brayda-Bruno M, Coviello D, Colombini A (2020) Intervertebral disc and end plate cell characterisation highlights annulus fibrosus cells as the most promising for tissue-specific disc degeneration therapy. Eur Cell Mater 39: 156-170.

De Luca P, Kouroupis D, Vigano M, PeruccaOrfei C, Kaplan L, Zagra L, de Girolamo L, Correa D, Colombini A (2019) Human diseased articular cartilage contains a mesenchymal stem cell-like population of chondroprogenitors with strong immunomodulatory responses. J Clin Med 8. pii: E423. DOI: $10.3390 /$ jcm8040423.

De Luca P, de Girolamo L, Perucca Orfei C, Viganò M, Cecchinato R, Brayda-Bruno M, Colombini A (2018) Vitamin D's effect on the proliferation and inflammation of human intervertebral disc cells in relation to the functional vitamin $\mathrm{d}$ receptor gene foki polymorphism. Int J Mol Sci 19: 2002. pii: E2002. DOI: 10.3390/ijms19072002.

Elmasry S, Asfour S, de Rivero Vaccari JP, Travascio F (2016) A computational model for investigating the effects of changes in bioavailability of insulin-like growth factor-1 on the homeostasis of the intervertebral disc. Comput Biol Med 78: 126-137.

Gendron C, Kashiwagi M, Lim NH, Enghild JJ, Thogersen IB, Hughes C, Caterson B, Nagase H (2007) Proteolytic activities of human ADAMTS-5: comparative studies with ADAMTS-4. J Biol Chem 282: 18294-18306.

Getting SJ, Mahoney DJ, Cao T, Rugg MS, Fries E, Milner CM, Perretti M, Day AJ (2002) The link module from human TSG-6 inhibits neutrophil migration in a hyaluronan- and inter-alpha -inhibitor-independent manner. J Biol Chem 277: 51068-51076.

Glant TT, Kamath RV, Bardos T, Gal I, Szanto S, Murad YM, Sandy JD, Mort JS, Roughley PJ, Mikecz K (2002) Cartilage-specific constitutive expression of TSG-6 protein (product of tumor necrosis factor alpha-stimulated gene 6) provides a chondroprotective, but not antiinflammatory, effect in antigen-induced arthritis. Arthritis Rheum 46: 2207-2218.

Gruber HE, Hoelscher GL, Ingram JA, Bethea S, Cox M, Hanley EN Jr (2015) Proinflammatory cytokines modulate the chemokine CCL2 (MCP-1) in human annulus cells in vitro: CCL2 expression and production. Exp Mol Pathol 98: 102-105.

Gruber HE, Hoelscher GL, Ingram JA, Bethea S, Norton HJ, Hanley EN Jr (2014a) Production and expression of RANTES (CCL5) by human disc cells and modulation by IL-1- $\beta$ and TNF- $\alpha$ in 3D culture. Exp Mol Pathol 96: 133-138.

Gruber HE, Ingram JA, Cox MD, Hanley EN Jr (2014b) Matrix metalloproteinase-12 immunolocalization in the degenerating human intervertebral disc and sand rat spine: biologic implications. Exp Mol Pathol 97: 1-5.

Hamamoto H, Miyamoto H, Doita M, Takada T, Nishida K, Kurosaka M (2012) Capability of nondegenerated and degenerated discs in producing inflammatory agents with or without macrophage interaction. Spine (Phila Pa 1976) 37: 161-167.

Hughes SP, Freemont AJ, Hukins DW, McGregor AH, Roberts S (2012) The pathogenesis of degeneration of the intervertebral disc and emerging therapies in the management of back pain. J Bone Joint Surg Br 94: 1298-1304.

Jimbo K, Park JS, Yokosuka K, Sato K, Nagata K (2005) Positive feedback loop of interleukin-1beta upregulating production of inflammatory mediators in human intervertebral disc cells in vitro. J Neurosurg Spine 2: 589-595.

Johnson ZI, Schoepflin ZR, Choi H, Shapiro IM, Risbud MV (2015) Disc in flames: roles of TNF- $\alpha$ and IL-1 $\beta$ in intervertebral disc degeneration. Eur Cell Mater 30: 104-117.

Kalb S, Martirosyan NL, Kalani MY, Broc GG, Theodore N (2012) Genetics of the degenerated intervertebral disc. World Neurosurg 77: 491-501.

Kang JD, Georgescu HI, McIntyre-Larkin L, Stefanovic-Racic M, Donaldson WF 3rd, Evans CH (1996) Herniated lumbar intervertebral discs spontaneously produce matrix metalloproteinases, nitric oxide, interleukin-6, and prostaglandin E2. Spine (Phila Pa 1976) 21: 271-277.

Kang JD, Stefanovic-Racic M, McIntyre LA, Georgescu HI, Evans CH (1997) Toward a biochemical understanding of human intervertebral 
disc degeneration and herniation. Contributions of nitric oxide, interleukins, prostaglandin E2, and matrix metalloproteinases. Spine (Phila Pa 1976) 22: 1065-1073.

Kepler CK, Markova DZ, Dibra F, Yadla S, Vaccaro AR, Risbud MV, Albert TJ, Anderson DG (2013) Expression and relationship of proinflammatory chemokine RANTES/CCL5 and cytokine IL-1 $\beta$ in painful human intervertebral discs. Spine (Phila Pa 1976) 38: 873-880.

Khan AN, Jacobsen HE, Khan J, Filippi CG, Levine M, Lehman RA Jr, Riew KD, Lenke LG, Chahine NO (2017) Inflammatory biomarkers of low back pain and disc degeneration: a review. Ann N Y Acad Sci 1410: 68-84.

Kim JH, Choi H, Suh MJ, Shin JH, Hwang MH, Lee HM (2013) Effect of biphasic electrical current stimulation on IL-1 $\beta$-stimulated annulus fibrosus cells using in vitro microcurrent generating chamber system. Spine 38: E1368-E1376.

Klawitter M, Quero L, Klasen J, Liebscher T, Nerlich A, Boos N, Wuertz K (2012a) Triptolide exhibits anti-inflammatory, anti-catabolic as well as anabolic effects and suppresses TLR expression and MAPK activity in IL-1 $\beta$ treated human intervertebral disc cells. Eur Spine J 21 Suppl 6: S850-S859.

Klawitter M, Quero L, Klasen J, Gloess AN, Klopprogge B, Hausmann O, Boos N, Wuertz K (2012b) Curcuma DMSO extracts and curcumin exhibit an anti-inflammatory and anti-catabolic effect on human intervertebral disc cells, possibly by influencing TLR2 expression and JNK activity. J Inflamm (Lond) 9: 29. DOI: 10.1186/1476-9255-9-29.

Le Maitre CL, Freemont AJ, Hoyland JA (2004) Localization of degradative enzymes and their inhibitors in the degenerate human intervertebral disc. J Pathol 204: 47-54.

Le Maitre CL, Freemont AJ, Hoyland JA (2005) The role of interleukin-1 in the pathogenesis of human intervertebral disc degeneration. Arthritis Res Ther 7: R732-745.

Le Maitre CL, Hoyland JA, Freemont AJ (2007) Catabolic cytokine expression in degenerate and herniated human intervertebral discs: IL-1beta and TNFalpha expression profile. Arthritis Res Ther 9: R77. DOI: 10.1186/ar2275.

Le Maitre CL, Richardson SMA, Baird P, Williamson B, Ross R, Freemont AJ, Hoyland JA (2003) IL-1; Role in degeneration of the intervertebral disc and its inhibition using IL-1Ra gene transfer. Molecular Therapy 7: S405-S405.

Liao ZW, Wu XH, Song Y, Luo RJ, Yin HP, Zhan SF, Li S, Wang K, Zhang YK, Yang C (2019) Angiopoietinlike protein 8 expression and association with extracellular matrix metabolism and inflammation during intervertebral disc degeneration. J Cell Mol Med 23: 5737-5750.

Liu C, Fei HD, Sun ZY, Tian JW (2015) Bioinformatic analysis of the microarray gene expression profile in degenerative intervertebral disc cells exposed to TNF- $\alpha$. Eur Rev Med Pharmacol Sci 19: 3332-3339.
Liu LT, Huang B, Li CQ, Zhuang Y, Wang J, Zhou Y (2011) Characteristics of stem cells derived from the degenerated human intervertebral disc cartilage endplate. PLoS One 6: e26285. DOI: 10.1371/journal. pone.0026285.

Lopa S, Ceriani C, Cecchinato R, Zagra L, Moretti M, Colombini A (2016) Stability of housekeeping genes in human intervertebral disc, endplate and articular cartilage cells in multiple conditions for reliable transcriptional analysis. Eur Cell Mater 31: 395-406.

Masuda K, An HS (2006) Prevention of disc degeneration with growth factors. Eur Spine J 15 Suppl 3: S422-4432.

Masuda K, Oegema TR Jr, An HS (2004) Growth factors and treatment of intervertebral disc degeneration. Spine (Phila Pa 1976) 29: 2757-2769.

Metsalu T, Vilo J (2015) ClustVis: a web tool for visualizing clustering of multivariate data using Principal Component Analysis and heatmap. Nucleic Acids Res 43:W566-570.

Millward-Sadler SJ, Costello P W, Freemont A J, Hoyland J A (2009) Regulation of catabolic gene expression in normal and degenerate human intervertebral disc cells: implications for the pathogenesis of intervertebral disc degeneration. Arthritis Res Ther 11: R65. DOI: 10.1186/ar2693.

Milner CM, Day AJ (2003) TSG-6: a multifunctional protein associated with inflammation. J Cell Sci 116: 1863-1873.

Minogue BM, Richardson SM, Zeef LA, Freemont AJ, Hoyland JA (2010) Characterization of the human nucleus pulposus cell phenotype and evaluation of novel marker gene expression to define adult stem cell differentiation. Arthritis Rheum 62: 3695-3705.

Molinos M, Almeida CR, Caldeira J, Cunha C, Goncalves RM, Barbosa MA (2015) Inflammation in intervertebral disc degeneration and regeneration. J $\mathrm{R}$ Soc Interface 12: 20150429. DOI: 10.1098/rsif.2015.0429.

Nakawaki M, Uchida K, Miyagi M, Inoue G, Kawakubo A, Kuroda A, Satoh M, Takaso M (2019) Sequential CCL2 expression profile after disc injury in mice. J Orthop Res 38: 895-901.

Osada R, Ohshima H, Ishihara H, Yudoh K, Sakai K, Matsui H, Tsuji H (1996) Autocrine/paracrine mechanism of insulin-like growth factor-1 secretion, and the effect of insulin-like growth factor-1 on proteoglycan synthesis in bovine intervertebral discs. J Orthop Res 14: 690-699.

Peck SH, McKee KK, Tobias JW, Malhotra NR, Harfe BD, Smith LJ (2017) Whole transcriptome analysis of notochord-derived cells during embryonic formation of the nucleus pulposus. Sci Rep 7: 10504. DOI: 10.1038/s41598-017-10692-5.

Phillips KL, Chiverton N, Michael AL, Cole AA, Breakwell LM, Haddock G, Bunning RA, Cross AK, Le Maitre CL (2013) The cytokine and chemokine expression profile of nucleus pulposus cells: implications for degeneration and regeneration of the intervertebral disc. Arthritis Res Ther 15: R213. DOI: $10.1186 / \operatorname{ar} 4408$. 
Phillips KL, Cullen K, Chiverton N, Michael AL, Cole AA, Breakwell LM, Haddock G, Bunning RA, Cross AK, Le Maitre CL (2015) Potential roles of cytokines and chemokines in human intervertebral disc degeneration: interleukin-1 is a master regulator of catabolic processes. Osteoarthritis Cartilage 23: 1165-1177.

Pockert AJ, Richardson SM, Le Maitre CL, Lyon M, Deakin JA, Buttle DJ, Freemont AJ, Hoyland JA (2009) Modified expression of the ADAMTS enzymes and tissue inhibitor of metalloproteinases 3 during human intervertebral disc degeneration. Arthritis Rheum 60: 482-491.

Power KA, Grad S, Rutges JP, Creemers LB, van Rijen MH, O'Gaora P, Wall JG, Alini M, Pandit A, Gallagher WM (2011) Identification of cell surfacespecific markers to target human nucleus pulposus cells: expression of carbonic anhydrase XII varies with age and degeneration. Arthritis Rheum 63: 3876-386.

Pratsinis H, Kletsas D (2007) PDGF, bFGF and IGF-I stimulate the proliferation of intervertebral disc cells in vitro via the activation of the ERK and Akt signaling pathways. Eur Spine J 16: 1858-1866.

Raj PP (2008) Intervertebral disc: anatomyphysiology-pathophysiology-treatment. Pain Pract 8: $18-44$.

Richardson SM, Doyle P, Minogue BM, Gnanalingham K, Hoyland JA (2009) Increased expression of matrix metalloproteinase-10, nerve growth factor and substance $\mathrm{P}$ in the painful degenerate intervertebral disc. Arthritis Res Ther 11: R126. DOI: 10.1186/ar2793.

Risbud MV, Shapiro IM (2014) Role of cytokines in intervertebral disc degeneration: pain and disc content. Nat Rev Rheumatol 10: 44-56.

Roberts S, Evans H, Menage J, Urban JP, Bayliss MT, Eisenstein SM, Rugg MS, Milner CM, Griffin S, Day AJ (2005) TNFalpha-stimulated gene product (TSG-6) and its binding protein, IalphaI, in the human intervertebral disc: new molecules for the disc. Eur Spine J 14: 36-42.

Rodrigues-Pinto R, Richardson SM, Hoyland JA (2014) An understanding of intervertebral disc development, maturation and cell phenotype provides clues to direct cell-based tissue regeneration therapies for disc degeneration. Eur Spine J 23: 1803 1814.

Romagnani P, Maggi L, Mazzinghi B, Cosmi L, Lasagni L, Liotta F, Lazzeri E, Angeli R, Rotondi M, Fili L, Parronchi P, Serio M, Maggi E, Romagnani S, Annunziato F (2005) CXCR3-mediated opposite effects of CXCL10 and CXCL4 on TH1 or TH2 cytokine production. J Allergy Clin Immunol 116: 1372-1379.

Rustenburg CME, Emanuel KS, Peeters M, Lems WF, Vergroesen PA, Smit TH (2018) Osteoarthritis and intervertebral disc degeneration: quite different, quite similar. JOR Spine 1: e1033. DOI: 10.1002/ jsp2.1033.
Rutges J, Creemers LB, Dhert W, Milz S, Sakai D, Mochida J, Alini M, Grad S (2010) Variations in gene and protein expression in human nucleus pulposus in comparison to annulus fibrosus and cartilage cells: potential associations with aging and degeneration. Osteoarthritis Cartilage 18: 416-423.

Sakai D (2008) Future perspectives of cell-based therapy for intervertebral disc disease. Eur Spine J 17 Suppl 4: 452-458.

Séguin CA, Pilliar RM, Madri JA, Kandel RA (2008) TNF-alpha induces MMP2 gelatinase activity and MT1-MMP expression in an in vitro model of nucleus pulposus tissue degeneration. Spine (Phila Pa 1976) 33: 356-365.

Shamji MF, Setton LA, Jarvis W, So S, Chen J, Jing L, Bullock R, Isaacs RE, Brown C, Richardson WJ (2010) Proinflammatory cytokine expression profile in degenerated and herniated human intervertebral disc tissues. Arthritis Rheum 62: 1974-1982.

Silacci P, Dayer JM, Desgeorges A, Peter R, Manueddu C, Guerne PA (1998) Interleukin (IL)-6 and its soluble receptor induce TIMP-1 expression in synoviocytes and chondrocytes, and block IL1-induced collagenolytic activity. J Biol Chem 273: 13625-13629.

Sinclair SM, Shamji MF, Chen J, Jing L, Richardson WJ, Brown CR, Fitch RD, Setton LA (2011) Attenuation of inflammatory events in human intervertebral disc cells with a tumor necrosis factor antagonist. Spine (Phila Pa 1976) 36: 1190-1196.

Sokol CL, Luster AD (2015) The chemokine system in innate immunity. Cold Spring Harb Perspect Biol 7. pii: a016303. DOI: 10.1101/cshperspect.a016303.

Solovieva S, Kouhia S, Leino-Arjas P, Ala-Kokko L, Luoma K, Raininko R, Saarela J, Riihimaki H (2004) Interleukin 1 polymorphisms and intervertebral disc degeneration. Epidemiology 15: 626-633.

Takahashi K, Tanabe K, Ohnuki M, Narita M, Ichisaka T, Tomoda K, Yamanaka S (2007) Induction of pluripotent stem cells from adult human fibroblasts by defined factors. Cell 131: 861-872.

Tang Y, Wang S, Liu Y, Wang X (2014) Microarray analysis of genes and gene functions in disc degeneration. Exp Ther Med 7: 343-348.

Tang X, Jing L, Chen J (2012) Changes in the molecular phenotype of nucleus pulposus cells with intervertebral disc aging. PLoS One 7: e52020. DOI: 10.1371/journal.pone.0052020.

Tesmer LA, Lundy SK, Sarkar S, Fox DA (2008) Th17 cells in human disease. Immunol Rev 223: 87113.

Tran CM, Markova D, Smith HE, Susarla B, Ponnappan RK, Anderson DG, Symes A, Shapiro IM, Risbud MV (2010) Regulation of CCN2/connective tissue growth factor expression in the nucleus pulposus of the intervertebral disc: role of Smad and activator protein 1 signaling. Arthritis Rheum 62: 1983-1992.

Tran CM, Schoepflin ZR, Markova DZ, Kepler CK, Anderson DG, Shapiro IM, Risbud MV (2014) CCN2 
suppresses catabolic effects of interleukin-1 $\beta$ through $\alpha 5 \beta 1$ and $\alpha \mathrm{V} \beta 3$ Integrins in nucleus pulposus cells: implications in intervertebral disc degeneration. J Biol Chem 289: 7374-7387.

Travascio F, Eltoukhy M, Cami S, Asfour S (2014) Altered mechano-chemical environment in hip articular cartilage: effect of obesity. Biomech Model Mechanobiol 13: 945-959.

Vergroesen PPA, Kingma I, Emanuel KS, Hoogendoorn RJW, Welting TJ, van Royen BJ, van Dieen JH, Smit TH (2015) Mechanics and biology in intervertebral disc degeneration: a vicious circle. Osteoarthritis Cartilage 23: 1057-1070.

Wang H, Zhou Y, Chu TW, Li CQ, Wang J, Zhang ZF, Huang B (2016) Distinguishing characteristics of stem cells derived from different anatomical regions of human degenerated intervertebral discs. Eur Spine J 25: 2691-2704.

Wang X, Wang H, Yang H, Li J, Cai Q, Shapiro IM, Risbud MV (2014) Tumor necrosis factor- $\alpha$ - and interleukin-1 $\beta$-dependent matrix metalloproteinase-3 expression in nucleus pulposus cells requires cooperative signaling via syndecan 4 and mitogenactivated protein kinase-NF- $\kappa \mathrm{B}$ axis: implications in inflammatory disc disease. Am J Pathol 184:25602572.

Wang J, Tian Y, Phillips KL, Chiverton N, Haddock G, Bunning RA, Cross AK, Shapiro IM, Le Maitre CL, Risbud MV (2013) Tumor necrosis factor $\alpha$ and interleukin-1 $\beta$-dependent induction of CCL3 expression by nucleus pulposus cells promotes macrophage migration through CCR1. Arthritis Rheum 65: 832-842.

Wang JR, Markova D, Anderson DG, Zheng ZM, Shapiro IM, Risbud MV (2011) TNF- $\alpha$ and IL-1 $\beta$ promote a disintegrin-like and metalloprotease with thrombospondin type I motif-5-mediated aggrecan degradation through syndecan-4 in intervertebral disc. J Biol Chem 286: 39738-39749.

Wang WJ, Yu XH, Wang C, Yang W, He WS, Zhang SJ, Yan YG, Zhang J (2015) MMPs and ADAMTSs in intervertebral disc degeneration. Clin Chim Acta 448: 238-246.

Weber KT, Jacobsen TD, Maidhof R, Virojanapa J, Overby C, Bloom O, Quraishi S, Levine M, Chahine NO (2015) Developments in intervertebral disc disease research: pathophysiology, mechanobiology, and therapeutics. Curr Rev Musculoskelet Med 8: 18-31.

Wisniewski HG, Vilcek J (1997) TSG-6: an IL-1/ TNF-inducible protein with anti-inflammatory activity. Cytokine Growth Factor Rev 8: 143-156.

Wuertz K, Quero L,Sekiguchi M, Klawitter M, Nerlich A, Konno S, Kikuchi S, Boos N (2011) The red wine polyphenol resveratrol shows promising potential for the treatment of nucleus pulposusmediated pain in vitro and in vivo. Spine (Phila Pa 1976) 36: E1373-E1384.

Wuertz K, Haglund L (2013) Inflammatory mediators in intervertebral disk degeneration and discogenic pain. Global Spine J 3: 175-184.
Xu H, Mei Q, He J, Liu G, Zhao J, Xu B (2014a) Correlation of matrix metalloproteinases- 1 and tissue inhibitor of metalloproteinases- 1 with patient age and grade of lumbar disk herniation. Cell Biochem Biophys 69: 439-444.

Xu HD, Mei Q, Xu B, Liu G, Zhao JN (2014b) Expression of matrix metalloproteinases is positively related to the severity of disc degeneration and growing age in the east asian lumbar disc herniation patients. Cell Biochem Biophys 70: 1219-1225.

Xu J, Wang W, Ludeman M, Cheng K, Hayami T, Lotz JC, Kapila S (2008) Chondrogenic differentiation of human mesenchymal stem cells in threedimensional alginate gels. Tissue Eng Part A 14:667680.

Yoo HJ, Yoon SS, Park SY, Lee EY, Lee EB, Kim JH, Song YW (2011) Gene expression profile during chondrogenesis in human bone marrow derived mesenchymal stem cells using a cDNA microarray. J Korean Med Sci 26: 851-858.

Zhang L, Smith DW, Gardiner BS, Grodzinsky AJ (2013a) Modeling the insulin-like growth factor system in articular cartilage. PLoS One 8: e66870. DOI: 10.1371/journal.pone.0066870.

Zhang Q, Huang M, Wang X, Xu X, Ni M, Wang Y (2012) Negative effects of ADAMTS-7 and ADAMTS-12 on endplate cartilage differentiation. J Orthop Res 30: 1238-1243.

Zhang W, Nie L, Wang Y, Wang XP, Zhao H, Dongol S, Maharjan S, Cheng L (2013b) CCL20 secretion from the nucleus pulposus improves the recruitment of CCR6-expressing Th17 cells to degenerated IVD Tissues. PLoS One 8: e66286. DOI: 10.1371/journal.pone.0066286.

\section{Web References}

1. https://www.oulu.fi/sites/default/files/news/ TheLancet_LowBackPain.pdf [06.05.2020]

2. https://earray.chem.agilent.com/earray/ [06.05.2020]

3. https://biit.cs.ut.ee/clustvis/ [06.05.2020]

\section{Discussion with Reviewers}

Reviewer 1: Please discuss the potential limitations when using passaged cells for this type of analysis, especially in relation to the fact that the number of adhering cells was not controlled for.

Authors: In general, although cell stability in culture has been demonstrated up to several passages, a potential limitation of using expanded cells consists in the partially loss of their tissue-specific phenotype. However, expanded cells had to be used because of the limited number of collected cells immediately after isolation, not sufficient to perform all the experiments. To indirectly control the number of adhering cells, cell counts have been performed after isolation and after each passage, by maintaining the 
same seeding density and assessing their doubling time throughout expansion. On the other hand, an advantage of using passaged cells is represented by the fact that future cell therapy will be based on cell expansion in order to obtain a suitable number of homogeneous cells. Therefore, the characterisation of the response to IL- $1 \beta$ of expanded cells would represent a more realistic clinical scenario.

Marianna Peroglio: In the last sentence of the abstract it is mentioned that the study allowed for the identification of specific molecular targets that can be either silenced (when pathological targets) or stimulated to counteract the inflammation What would be the key molecular targets for each strategy? Which strategy could have a better chance of success in humans?

Authors: Among the three kind of analysed cells, EPCs showed the most anti-inflammatory response to IL-1 $\beta$ treatment, along with a protective attitude to repress the inflammation-activated pathways involved in white blood cell recruitment. For this reason, in an inflammatory context, they appear as the more promising tool for cell therapy. On the other hand, if considering the identified molecular target, a huge plethora of catabolic and inflammatory mediators were upregulated in presence of IL- $1 \beta$, and IL-1Ra, IGFs and TSG6, in particular, appeared to be suitable candidates to be stimulated in IVD and EP cells for counteracting degenerative processes. These results suggested exploiting EPCs and stimulating the release of the identified anti-inflammatory and anabolic mediators as a potentially successful strategy to control inflammation.

Marianna Peroglio: In a previous study, the authors have investigated the response of osteoarthritic cartilage to IL-1 $\beta$ stimulation. What similarities and differences can be drawn between osteoarthritic chondrocytes' response to IL- $1 \beta$ stimulation and IVD and EP cells response to this same cytokine?

Authors: Maintaining the same experimental conditions, some similarities were observed in terms of catabolic and secretory markers produced by IVD and EP cells after IL-1 $\beta$ treatment and osteoarthritic chondrocytes. In particular, in all the analysed cell populations, the inflammatory stimulus promoted the upregulation of specific MMPs (1, 3 and 13), without a corresponding production of their TIMPs ( 1 and 3 ) to balance the catabolic induction. Rather, IVD and EP cells showed a downregulation of TIMP3. In both spine cells and osteoarthritic chondrocytes, IL-1 $\beta$ treatment also increased the production of a plethora of secretory molecules, such as the antiinflammatory IL-1Ra, GM-CSF and IL-11 as well as the pro-inflammatory ICAM- 1 and IL- $1 \beta$. In general, EPCs and osteoarthritic chondrocytes were the most responsive cells to IL-1 $\beta$. The former showing metabolic inhibition, whereas the latter showing an increased secretion of the pro-inflammatory/ modulatory molecules. Moreover, IL-1 $\beta$ promoted a more pro-inflammatory behaviour of NPCs, AFCs and osteoarthritic chondrocytes, resulting from an increased secretion of the pro-inflammatory IL-6sR, MIP-1- $\alpha$, MIP-1- $\beta$ and IL-8.

Marianna Peroglio: Could the authors comment on the inter-donor variability in terms of response to IL-1 $\beta$ and how this could potentially impact the envisioned therapy?

Authors: The inter-donor variability is a fundamental aspect to consider when using primary cells. In the present study, despite the inter-donor variability, markers of specific biological processes were identified as being modulated by IL-1 $\beta$ treatment. However, further evaluations should be performed to confirm the results obtained in a pool of donors in single donors too. Confirming of these results and performing specific functional tests would add further value to the therapeutic potential of the identified molecular targets.

Editor's note: The Scientific Editor responsible for this paper was Mauro Alini. 